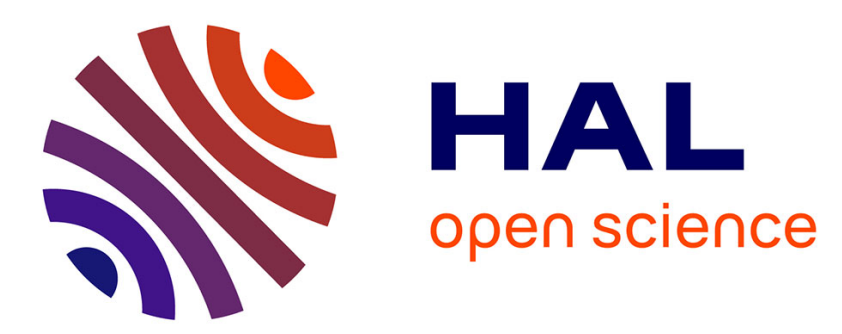

\title{
Review of nanomaterial aging and transformations through the life cycle of nano-enhanced products
}

Denise M. Mitrano, Sylvie Motellier, Simon Clavaguera, Bernd Nowack

\section{To cite this version:}

Denise M. Mitrano, Sylvie Motellier, Simon Clavaguera, Bernd Nowack. Review of nanomaterial aging and transformations through the life cycle of nano-enhanced products. Environment International, 2015, 77, pp.132-147. 10.1016/j.envint.2015.01.013 . cea-01344057

\section{HAL Id: cea-01344057 https://hal-cea.archives-ouvertes.fr/cea-01344057}

Submitted on 11 Jul 2016

HAL is a multi-disciplinary open access archive for the deposit and dissemination of scientific research documents, whether they are published or not. The documents may come from teaching and research institutions in France or abroad, or from public or private research centers.
L'archive ouverte pluridisciplinaire HAL, est destinée au dépôt et à la diffusion de documents scientifiques de niveau recherche, publiés ou non, émanant des établissements d'enseignement et de recherche français ou étrangers, des laboratoires publics ou privés. 
Review

\title{
Review of nanomaterial aging and transformations through the life cycle of nano-enhanced products
}

\author{
Denise M. Mitrano ${ }^{\mathrm{a}, *}$, Sylvie Motellier ${ }^{\mathrm{b}}$, Simon Clavaguera ${ }^{\mathrm{b}}$, Bernd Nowack $^{\mathrm{a}}$ \\ ${ }^{a}$ EMPA - Swiss Federal Laboratories for Material Science and Technology, Technology and Society Laboratory, Lerchenfeldstrasse 5, CH-9014 St. Gallen, Switzerland \\ b CEA Commissariat à l'Energie Atomique et aux Energies Alternatives, 17, Rue des Martyrs, 38054 Grenoble Cedex 9, France
}

\section{A R T I C L E I N F O}

\section{Article history:}

Received 24 November 2014

Received in revised form 21 January 2015

Accepted 22 January 2015

Available online 18 February 2015

\section{Keywords:}

Nanomaterials

Transformation

Aging

Nano-product

Life cycle

\begin{abstract}
A B S T R A C T
In the context of assessing potential risks of engineered nanoparticles (ENPs), life cycle thinking can represent a holistic view on the impacts of ENPs through the entire value chain of nano-enhanced products from production, through use, and finally to disposal. Exposure to ENPs in consumer or environmental settings may either be to the original, pristine ENPs, or more likely, to ENPs that have been incorporated into products, released, aged and transformed. Here, key product-use related aging and transformation processes affecting ENPs are reviewed. The focus is on processes resulting in ENP release and on the transformation(s) the released particles undergo in the use and disposal phases of its product life cycle for several nanomaterials $\left(\mathrm{Ag}, \mathrm{ZnO}, \mathrm{TiO}_{2}\right.$, carbon nanotubes, $\mathrm{CeO}_{2}, \mathrm{SiO}_{2}$ etc.). These include photochemical transformations, oxidation and reduction, dissolution, precipitation, adsorption and desorption, combustion, abrasion and biotransformation, among other biogeochemical processes. To date, few studies have tried to establish what changes the ENPs undergo when they are incorporated into, and released from, products. As a result there is major uncertainty as to the state of many ENPs following their release because much of current testing on pristine ENPs may not be fully relevant for risk assessment purposes. The goal of this present review is therefore to use knowledge on the life cycle of nano-products to derive possible transformations common ENPs in nano-products may undergo based on how these products will be used by the consumer and eventually discarded. By determining specific gaps in knowledge of the ENP transformation process, this approach should prove useful in narrowing the number of physical experiments that need to be conducted and illuminate where more focused effort can be placed.
\end{abstract}

(c) 2015 Elsevier Ltd. All rights reserved.

\section{Contents}

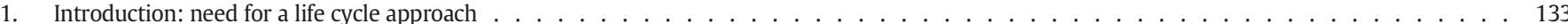

2. Approach to estimating likely ENP release and transformation from commercial products . . . . . . . . . . . . . . . . . . . . . . . . 133

3. Product independent reactions . . . . . . . . . . . . . . . . . . . . . . . . . . . . . . . 135

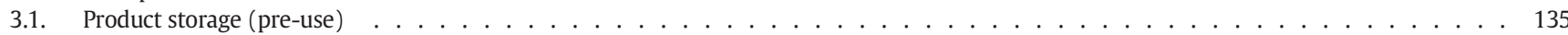

3.2. End of life $($ disposal $) \ldots \ldots \ldots \ldots \ldots$

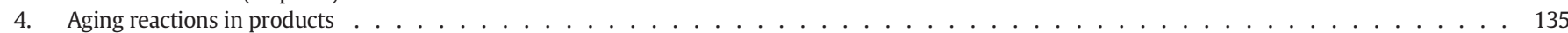

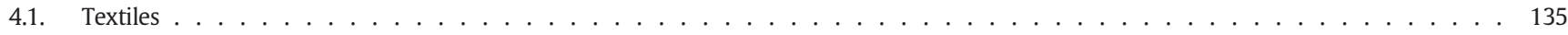

4.2. Sunscreens, cosmetics, personal care products and cleaning agents . . . . . . . . . . . . . . . . . . . . . . . . 137

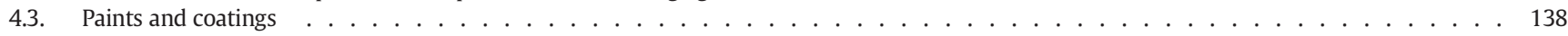

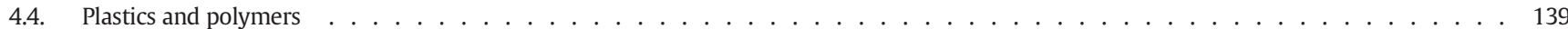

4.5. ENP in the food sector: additives, supplements, containers and packaging . . . . . . . . . . . . . . . . . . . . . . . . 140

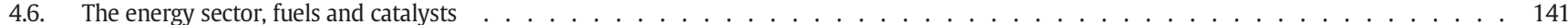

4.7. Consumer electronics and semiconductors . . . . . . . . . . . . . . . . . . . . . . . . . . . . . . 141

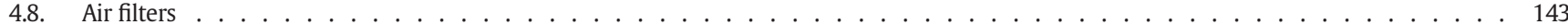

5. Implications of transformation reactions . . . . . . . . . . . . . . . . . . . . . . . . . . . . 143

5.1. Grouping particle transformation processes through the life cycle of nano-products . . . . . . . . . . . . . . . . . . . 143

5.2. Implication for future risk assessment protocols . . . . . . . . . . . . . . . . . . . . . . . . . . . . . . 144

5.3. Moving toward building a useable database . . . . . . . . . . . . . . . . . . . . . . . . . 144

\footnotetext{
* Corresponding author.

E-mail address: denise.mitrano@empa.ch (D.M. Mitrano).
} 


\section{Introduction: need for a life cycle approach}

The development of new products implementing engineered nanoparticles (ENPs) may prove to be a cost effective and sustainable alternative to using traditional materials (Kuhlbusch et al., 2009; Savolainen et al., 2010). However, there are major knowledge gaps in regard to the potential health and environmental effects posed by ENP (Handy et al., 2008; Nowack and Bucheli, 2007; Klaine et al., 2012). In the context of assessing these potential risks, a life cycle approach (covering production, use and disposal of a chemical or product) can represent a holistic view on their impacts (Som et al., 2010). Considering that life cycles of many ENPs are determined by their application within products, it becomes clear that relevant exposure scenarios and ENP aging and transformations are strongly dependent on the life cycle of the nano-enhanced products themselves. While the product manufacturing portion of the life cycle will likely be in a controlled, industrial setting, the use and disposal of nano-products in the consumer realm will be decidedly less predictable and include more variables. ENP release from textiles (Benn and Westerhoff, 2008; Windler et al., 2012; Geranio et al., 2009), paints and facades (Kaegi et al., 2008, 2010a; O'Brien and Cummins, 2010), sunscreens and personal care products (Auffan et al., 2010; Botta et al., 2011), polymers (Reed et al., 2013), food packaging (O'Brien and Cummins, 2010), foodstuffs (Weir et al., 2012) and a multitude of other products (Benn et al., 2010) have all been investigated in laboratory settings. As much of ENPs are destined eventually to flow through wastewater treatment facilities after nano-product use, the release of ENPs from these plants has also been explored (Kiser et al., 2009; Westerhoff et al., 2011; Kaegi et al., 2011, 2013).

These considerations highlight the fact that since ENPs will readily be aged and/or transformed during a product's life cycle, it would be prudent to also consider how these by-products differ from pristine ENPs in terms of hazard, fate, transport and environmental impact. The current experimental regime in testing ENP transformations in the laboratory, technosphere (e.g. waste water treatment, waste incineration, recycling systems), biosphere and environment does not focus on aged or transformed ENPs. Most experimental schemes use pristine ENPs in a variety of conditions in a laboratory setting; which can be considered mechanistic studies. Alternatively, aged particles (i.e. those that are stored or otherwise transformed by chemical or physical factors so that they no longer have the same characteristics of their pristine counterparts) or particles released during product use could provide a more realistic basis for studying ENPs in the environment. Less research has been focused on mimicking the product life cycle to understand aged or product released particles.

There have been several reviews published in recent years concerning the release and environmental transformation of ENPs. Lowry et al. outlined numerous environmental transformation processes and presented the idea that while the effects measured for pristine ENPs may be representative of exposures occurring at manufacturing or processing sites, environmental exposures will consist solely of transformed ENPs and so data related to pristine ENPs may not be predictive of real-world scenarios (Lowry et al., 2012). Using hypothetical test cases, Nowack et al. examined the likely fate of a wide range of ENPs released from products (Nowack et al., 2012). The authors concluded that it is not possible to assess the environmental risks by only studying the pristine material and that alteration and transformation processes need to be considered when determining fate. Other ENP release and transformation reviews were material specific, such as Ag ENPs (Levard et al., 2012; Reidy et al., 2013), carbon nanotubes (CNTs) (Petersen et al., 2011; Nowack et al., 2013; Köhler et al., 2008) or composite materials (Froggett et al., 2014). Understanding these transformations of pristine ENPs is essential to correctly extrapolate the fate of particles during the use and disposal phases of a nano-enhanced-product's life cycle. By better understanding probable endpoints of aged materials, ENP fate can be better incorporated into the general structure of risk assessment.

The goal of this present review is to derive the possible transformations common ENPs may undergo during the use or disposal of nanoproducts, therefore providing an analysis what happens to ENP before they enter the environment. Here, transformation is considered a change/alteration to either: 1 ) the primary particle, 2 ) the coating of the ENP, or 3 ) the conformation of a particle community (e.g. agglomerate formation or (de)agglomeration). In many instances, a particle may experience multiple transformation processes in sequence (e.g. surface oxidation followed by dissolution). We determined a selection of some of the most important ENP categories $\left(\mathrm{Ag}, \mathrm{TiO}_{2}, \mathrm{ZnO}\right.$, and $\left.\mathrm{CNT}\right)$ and uses (textiles, personal care products, etc.) based on the comprehensive probabilistic material flow modeling analysis of Sun et al. (2014). Other ENP categories that were not reviewed by Sun et al., yet feature prominently in some applications, are discussed in relation to appropriate products. Specific applications of ENPs were investigated, and through understanding how the ENPs will be used, we predicted the likely releases, aging processes, and transformations of the ENPs. We therefore determine the most relevant ENP transformation process for each product; an approach which may prove useful in narrowing the number of physical experiments that need to be conducted and illuminate where more focused effort can be placed.

\section{Approach to estimating likely ENP release and transformation from commercial products}

Specific applications of ENM in commercial products will ultimately determine the type and extent of transformations a given ENM may undergo. Environmental and biological systems are dynamic and variable; many physico-chemical changes will impact ENPs, their (incidental) surface coatings, and reactions before and after release from consumer goods. Understanding the impact of these transformations may help forecast the benefits and/or risks associated with their use. Here, we make an amalgam of these two approaches where we consider which applications a selection of nanomaterials $\left(\mathrm{Ag}, \mathrm{TiO}_{2}, \mathrm{ZnO}\right.$, and $\left.\mathrm{CNT}\right)$ are used in and which chemical and/or physical ENP transformations are most likely based on the life cycle of these products. By considering the total amount of nanomaterials produced (Fig. 1, top panel), how those materials are used in each product category (Fig. 1, center panel) and the relative distribution of which sectors each ENP is used in (Fig. 1, bottom panel) we can better understand the scope and extent of possible transformations of ENPs in products. In the following sections, we evaluate the possible particle transformations based on how ENPs will be implemented into products, how those products will be used, and what use or environmental stresses the product is likely to encounter. Based on these specific applications of ENPs, we present a selection of possible transformations and aging reactions based on their typical use in consumer goods.

Applications were considered if they made up 5\% or more of the market share value for nano-enhanced products as determined by a recent life-cycle based material flow modeling study (Sun et al., 2014). Additional ENP varieties and/or product uses were included beyond this where the authors felt that market presence may increase 

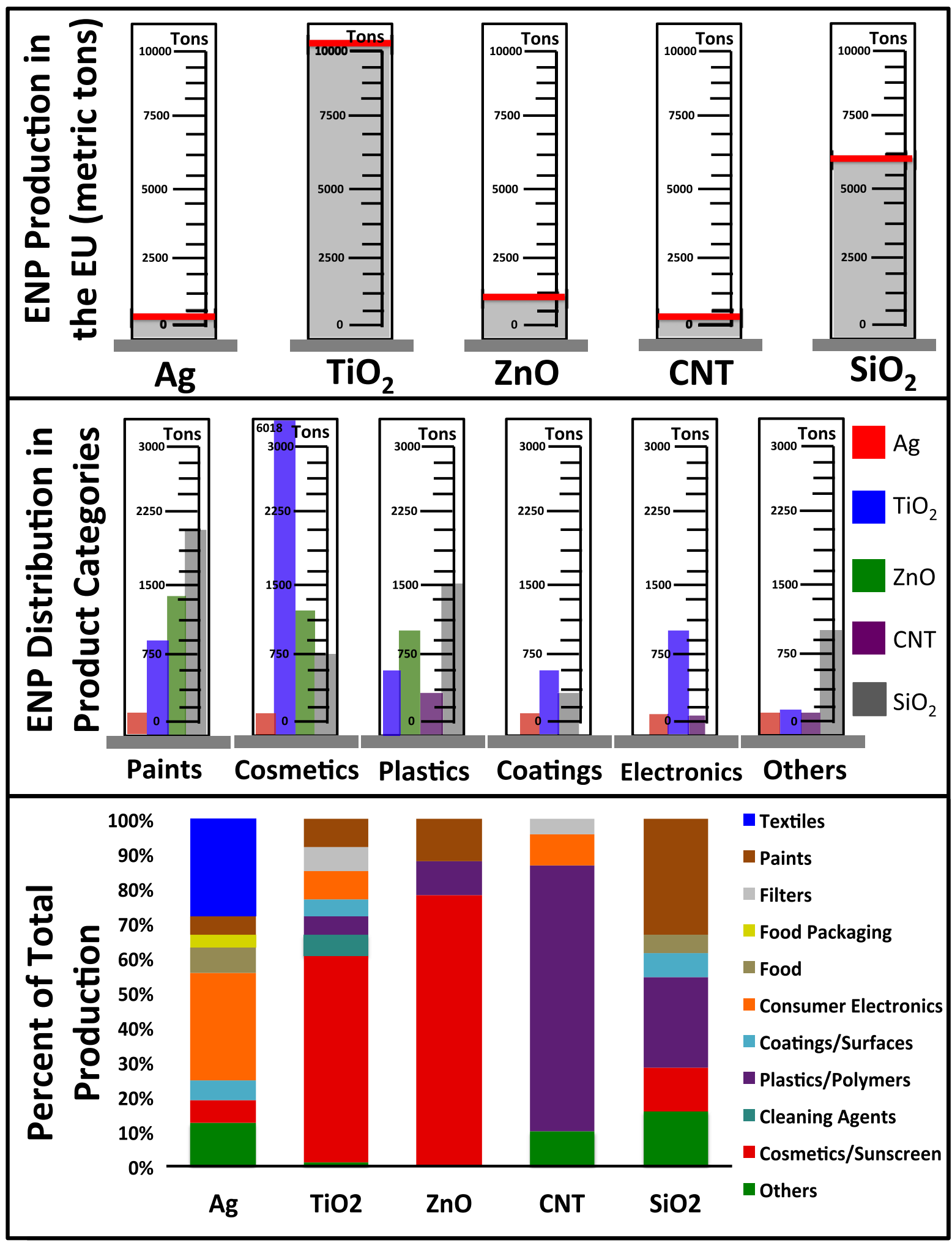

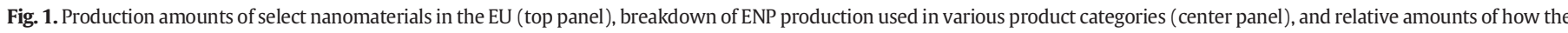

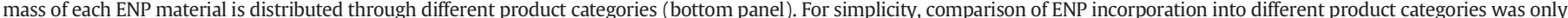

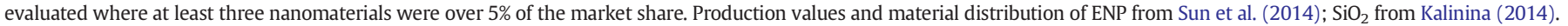

dramatically in the coming years. We acknowledge that many applications bridge two (or more) market category divisions, for example edible coatings to prevent food spoilage could be included in either the "food" category or the "coatings" category. Recognizing that significant overlaps exist, we attempted to limit the analysis of transformations to only one group per product for simplicity. Therefore, transformations that are inherently applicable to multiple product categories will be addressed only once and referenced thereafter. 


\section{Product independent reactions}

\subsection{Product storage (pre-use)}

While in storage, ENPs incorporated into products will be exposed to the atmosphere, humidity and variable temperatures. Meanwhile, changes in the crystal structure and/or the particle surface may occur and defects affecting product robustness may be observed over time (Kenning et al., 2011). Change in particle size is a common trend, such as an example reported by Thurber et al. (2012), unprotected ZnO powders almost doubled in diameter after four years of exposure to ambient air. In another example of particle growth, formation of $\mathrm{ZnO}$ nanocrystals in powder form at room temperature was dependent on relative humidity and partial pressure (Ali and Winterer, 2009). Changes to the surface coatings of the pristine materials can also occur, such as the desorption of the polyethyleneimine (PEI) coatings on MWCNTs stored in water (Petersen et al., 2011) or enzymatic degradation of the particle coatings. Biotransformations of entire ENMs are likely to be slow, however, with Flores-Cervantes and colleagues suggesting the half life of CNT degradation through this process by horseradish peroxidase upwards of 80 years under environmental conditions (Flores-Cervantes et al., 2014). Another example of changes to ENPs in a product from when they are manufactured to when a consumer can use them is from a study by Lombi et al., where the authors show textiles that contain nano-Ag already have a suite of different forms when purchased - a clear indication of ENP transformation either during manufacturing of the product or when stored (Lombi et al., 2014).

Oxidation of metallic ENM is a prominent aging process during product storage. In one study where copper ENPs were left unattended for six years under ambient conditions, a thick oxide coating was formed on the particles' surface; increasing the particle size by up to $50 \%$ where subsequently these aged ENPs dissolved more readily (Mudunkotuwa et al., 2012). However, oxidation may affect various types of ENPs differently. When studying core/shell clusters, Yin et al. showed that the chemical distribution between core and shell is the determining factor as to whether oxidation takes place (Yin et al., 2012). Quantum dots (QDs) were also found to undergo oxidation, even when capped with an organic ligand. In their study, Katari et al. aged TOPO-capped CdSe QDs in air for several weeks (Katari et al., 1994). $\mathrm{SeO}_{2}$ was recovered after one day of exposure, which desorbed from the surface of the QD, while $\mathrm{Cd}$ was not oxidized because of the TOPO protection. The instability of these TOPO coated nanocrystals was confirmed by Alivisatos (1996), as when exposed to visible light, CdS and CdSe form sulfate or selenate, respectively, that evaporates from the surface as a molecular species to leave reduced $\mathrm{Cd}$ and a newly exposed CdS or CdSe layer.

Under most atmospheric conditions, Ag becomes tarnished. Formation of $\mathrm{Ag}_{2} \mathrm{~S}$ is the most common corrosion product in indoor air (McMahon et al., 2005a) while strong oxidants, such as $\mathrm{NO}_{\mathrm{x}}$ and ozone, can accelerate $\mathrm{Ag}_{2} \mathrm{~S}$ formation significantly (Rice et al., 1981; Kim, 2003; Volpe and Peterson, 1989). Alternatively, transformation of $\mathrm{Ag}$ to $\mathrm{AgCl}$ is usually more dominant in outdoor environments, where environmental components including ozone, UV light and humidity can accelerate atmospheric corrosion (Lin and Frankel, 2013; Watanabe et al., 2006). Humidity and sweat may also promote the generation of secondary NPs. Indeed, the generation of Ag NPs has been observed in the vicinity of parent particles (and bulk metals) in ambient conditions with variable relative humidity (Glover et al., 2011). The formation proceeds in three stages: 1) oxidation and dissolution of $\mathrm{Ag}$ from the surface of the pristine particles, followed by 2) diffusion of the $\mathrm{Ag}^{+}$ions in an absorbed water layer, and finally 3) formation of a new NP by chemical transformation and/or photoreduction. The formation of new Ag seeds should be favored by widely used capping agents or stabilizers: PVP, citrates and aminoalkylsilanes, for instance, are known to reduce $\mathrm{Ag}^{+}$(Huang et al., 1996).
We can therefore conclude that the particles present in products during use and/or storage may be significantly changed compared to the pristine ENM even without undergoing any processes specific to the actual product.

\subsection{End of life (disposal)}

At the end of the life cycle, many products will be disposed as solid waste, either as raw products transported directly to a landfill or as incineration byproducts. For the purposes of this review, deposition of ENPs in landfills is considered a final sink. In many European countries, incineration of waste is common, but in the United States, only approximately $15 \%$ of the total seven million dry tons of biosolids were incinerated in 2007 (Association, 2007) (though, increased interests in power generation from biosolids may raise this figure (Stillwell et al., 2010)). Firstly, the surface coatings of ENPs that are incinerated would be burned off and the particle surface would become oxidized. A second consideration is that many ENPs would not enter the incineration plant in pristine form, but rather as already transformed particles (e.g. $\mathrm{Ag}_{2} \mathrm{~S}$ ). Impellitteri et al. provided XAS data suggesting that significant amounts of $\mathrm{Ag}$ in incinerated biosolid samples (30-50\%) converted back to elemental silver while the reminder was still associated with sulfate and sulfhydryl groups (Impellitteri et al., 2013). Residual material would remain in the bottom ash or the filter ash which may have several uses; one of which is for building roads. Direct release from waste incineration to the air was found to be extremely low given the high efficiency of flue gas cleaning (Walser et al., 2012). In this case, fully transformed ENPs (of various starting and ending compositions) may directly go into the environment. Depending on incineration temperatures, transformation of the crystal matrix could also be possible (Roes et al., 2012). This process could be analogous to the transformations observed in the annealing processes of some NP synthesis techniques. Structural transformations were found, for instance, under calcination of the anatase form of $\mathrm{TiO}_{2}$ (Tripathi et al., 2013). The anatase crystalline form of $\mathrm{TiO}_{2}$ is less stable and has a lower density than rutile and phase transformation of anatase to rutile occurs at approximately $600{ }^{\circ} \mathrm{C} / 700{ }^{\circ} \mathrm{C}$ (Allen et al., 1998). However, stable ENPs may also remain unchanged as was shown for $\mathrm{CeO}_{2}$-NP that was added to a municipal waste incinerator (Walser et al., 2012).

Acids are also used in the incineration process to clean flue and filter ash in the hopes of metal recovery for elements such as $\mathrm{Zn}$. For $\mathrm{TiO}_{2}$ particles, this may affect any remaining surface coating but would not dissolve the particle itself. On the other hand, $\mathrm{ZnO}$ would be completely dissolved (Mueller et al., 2013). Plastics may also be acid treated when being recycled, where this is used as a preparation/cleaning step to remove dirt or debris from the surface. Here again, $\mathrm{TiO}_{2}$ would be resistant to change and $\mathrm{ZnO}$ (and similarly Ag ENP) would entirely dissolve. Additionally, any organic macromolecules, biomolecules, or coatings bound to the surface could be "digested" in this step, revealing the underlying "bare" nanoparticles. Finally, some acids, such as nitric acid, can oxidize, shorten, and eventually destroy CNTs after prolonged exposure.

\section{Aging reactions in products}

\subsection{Textiles}

Four main factors affect the quantity of ENP release and subsequent transformations over the lifetime of a textile, including: 1) incorporation into the material (location, adhesion to matrix, textile composition, ENP form), 2) use of textile (sweat, temperature, abrasion), 3) cleaning/ washing technique and associated chemicals (e.g. bleach and detergent) and 4) disposal. Depending on material design and external impacts to the textile, ENPs may be released as single particles, agglomerates, embedded in the matrix, and/or as dissolved ions (Benn and Westerhoff, 2008; Geranio et al., 2009; Lorenz et al., 2012). Where the release occurs 
Known and probable transformations of ENPs imbedded in textiles. Specific studies cited when possible.

\begin{tabular}{|c|c|c|c|c|c|}
\hline $\begin{array}{l}\text { Transformation } \\
\text { process }\end{array}$ & ENP affected & Life cycle activity & Change to particle & Possible implications & Representative example(s) \\
\hline \multirow[t]{4}{*}{ Oxidation } & $\mathrm{Ag}$ & Washing & Oxidation by $\mathrm{O}_{2}$, Dissolution & $\begin{array}{l}\text { - Increased toxicity } \\
\text { - Decreased effectiveness in product over time }\end{array}$ & $\begin{array}{l}\text { - Release of } \mathrm{Ag}^{+} \text {in simulated washing cycle with surfactants } \\
\text { (Geranio et al., 2009) } \\
\text { - Release of } \mathrm{Ag}^{+} \text {and Ag NP from conventional and nano-textiles } \\
\text { (Mitrano et al., 2014b) }\end{array}$ \\
\hline & $\mathrm{Ag}$ & $\begin{array}{l}\text { Contact with bleaching, } \\
\text { oxidizing agents }\end{array}$ & $\begin{array}{l}\text { Dissolution, phase } \\
\text { transformation, speciation } \\
\text { change }\end{array}$ & $\begin{array}{l}\text {-Dissolution } \\
\text { - Formation of AgCl } \\
\text { • Leached Ag goes to WWTP and biosolids in AgCl form }\end{array}$ & $\begin{array}{l}\text { - Hypochlorite/detergent solution converts Ag to AgCl in the presence of } \\
\mathrm{NaCl} \text { (Geranio et al., 2009; Impellitteri et al., 2009) } \\
\text { • Change in Ag speciation after washing textiles (Lombi et al., 2014) }\end{array}$ \\
\hline & $\mathrm{Ag}$ & $\begin{array}{l}\text { Contact with detergents/ } \\
\text { complexing agents }\end{array}$ & Ag complexation, stabilization & Formation of stable ENP suspension & $\mathrm{N} / \mathrm{A}$ \\
\hline & ENP Coating & Various & Destruction of coating & Change to particle stability, oxidation extent, toxicity, etc. & $\mathrm{N} / \mathrm{A}$ \\
\hline \multirow[t]{3}{*}{ Dissolution } & $\mathrm{Ag}, \mathrm{ZnO}, \mathrm{SiO}_{2}$ & Washing & Ion formation & Increased toxicity & $\begin{array}{l}\text { Wash in DI water nearly all impregnated Ag released in the first few cycles } \\
\text { (Benn and Westerhoff, 2008; Geranio et al., 2009; Lorenz et al., 2012) }\end{array}$ \\
\hline & All & Wearing & Coating alteration & $\begin{array}{l}\text { - Exposure to sweat or urine coats particles with } \mathrm{AgCl} \\
\cdot \mathrm{pH} \text { of sweat changes }[\mathrm{Ag}] \text { released }\end{array}$ & $\begin{array}{l}\text { - Cease } \mathrm{Ag}^{+} \text {release (Quadros et al., 2013; von Götz et al., 2013) } \\
\text { - Normal skin pH had lowest [Ag] release (Kulthong et al., 2010) }\end{array}$ \\
\hline & $\mathrm{Ag}, \mathrm{ZnO}$ & $\begin{array}{l}\text { Contact with detergents/ } \\
\text { complexing agents }\end{array}$ & Ag complexation, stabilization & Formation of stable ENP suspension & $\mathrm{N} / \mathrm{A}$ \\
\hline \multirow[t]{2}{*}{ Precipitation } & $\mathrm{Ag}$ & Washing & $\mathrm{AgCl}$ formation & Precipitation and/or decreased toxicity & $\begin{array}{l}\text { Nature of (in)soluble Ag species varies as a function of total } \mathrm{Ag} \text { and } \mathrm{Cl}^{-} \\
\text {(Levard et al., 2013) }\end{array}$ \\
\hline & $\mathrm{Ag}$ & Exposure to air & Metallic Ag particle formation & Generation of small secondary particles & Small Ag particles formed in humid conditions (Glover et al., 2011) \\
\hline Reduction & $\mathrm{Ag}$ & Washing & Formation of $\mathrm{Ag}(0)$ from $\mathrm{Ag}^{+}$ & "New" particle formation & $\mathrm{N} / \mathrm{A}$ \\
\hline \multirow[t]{3}{*}{ UV irradiation } & $\mathrm{Ag}, \mathrm{ZnO}$ & Wearing in sun & Oxidation of particle surface & Change in reactivity & N/A \\
\hline & & WWTP disinfection & $\mathrm{N} / \mathrm{A}$ & Attempt to purify water & - No removal of Ag ENP at neutral pH (Yuan et al., 2013) \\
\hline & ENP Coating & Wearing in sun & Destruction of coating & $\begin{array}{l}\text { - Change to particle stability } \\
\text { (agglomeration and sedimentation) } \\
\text { • Susceptibility to oxidation and dissolution }\end{array}$ & - Degradation of gum arabic coating in sunlight (Cheng et al., 2011) \\
\hline Incineration & All & After disposal & Change in chemistry & $\begin{array}{l}\text { - Reduce agglomeration of particles } \\
\text { - Trace amounts of Ag left in bottom ash }\end{array}$ & $\begin{array}{l}\text { - TEM image after textile burned in furnace (Kulthong et al., 2010) } \\
\text { - Modeling result only (Gottschalk et al., 2010) }\end{array}$ \\
\hline \multirow[t]{2}{*}{ Release of ENP } & $\mathrm{Ag}, \mathrm{TiO}_{2}$ & $\begin{array}{l}\text { Abrasion and sweat, } \\
\text { Abrasion and washing }\end{array}$ & Release of Ag & $\begin{array}{l}\text { - pH of sweat contributes to release } \\
\text { (alkaline increased release) } \\
\text { - Physical stress may mobilize more particles } \\
\text { - Compared to other pathways, minor exposure }\end{array}$ & $\begin{array}{l}\text { - Migration of textiles into artificial sweat under physical stress } \\
\text { (particles specified) (von Götz et al., 2013) } \\
\text { - Chemical mobilization of Ag into sweat (form unspecified) } \\
\text { (Windler et al., 2012; Kulthong et al., 2010; Yan et al., 2012) } \\
\text { - Release of particles during the laundry wash cycle } \\
\text { (Lombi et al., 2014; Mitrano et al., 2014b) }\end{array}$ \\
\hline & $\mathrm{Ag}, \mathrm{TiO}_{2}$ & Abrasion and sweat & Re-precipitation & $\begin{array}{l}\text {-Possible formation of AgCl, stabilized as Ag-chloro-complexes } \\
\text { - Compared to other pathways, minor exposure }\end{array}$ & $\begin{array}{l}\text { - Migration of textiles into artificial sweat under physical stress } \\
\text { (von Götz et al., 2013) }\end{array}$ \\
\hline
\end{tabular}




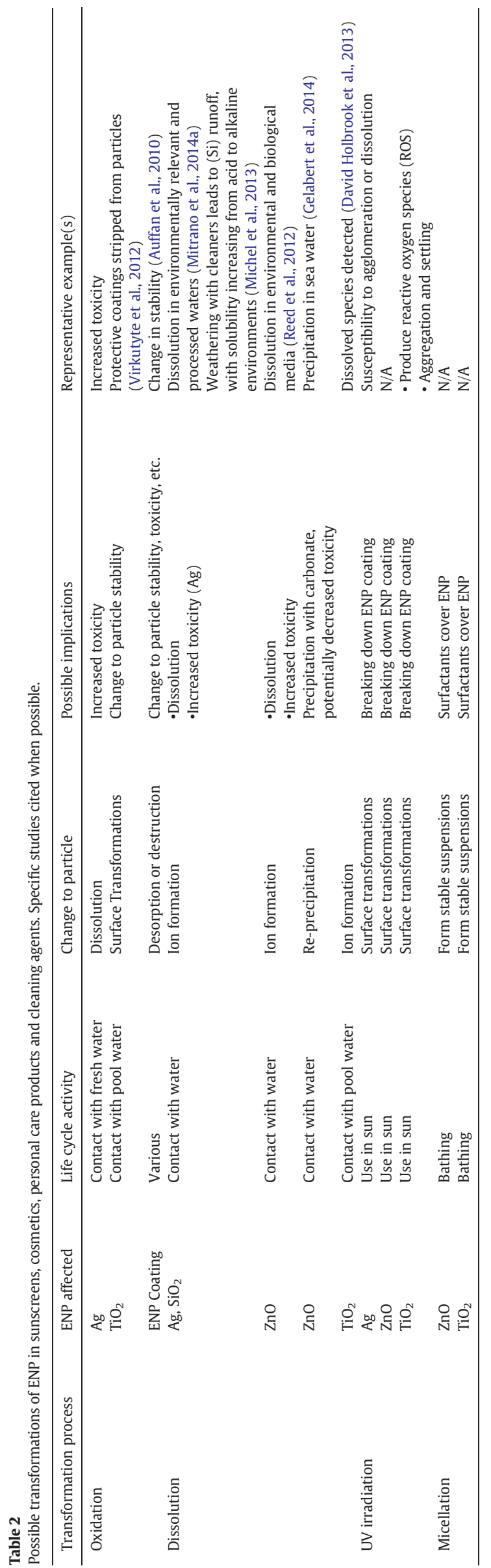

(i.e. during washing, wear, directly to the environment, or after product disposal) will also play a large role in the types of transformations Ag ENPs, the most common ENP encountered in textile applications, may undergo following release (Table 1). A relatively large fraction of Ag ENPs in textiles will likely be released into wastewater after washing. Other sources of incidental Ag ENP release, such as release to air from abrasion, contact with skin, biological fluids (e.g. sweat, urine) or incineration are less substantial.

Incorporation of zerovalent silver into fabrics is common and thus in these instances oxidation from $\mathrm{Ag}(0)$ to $\mathrm{Ag}(\mathrm{I})$ is a prerequisite for the appearance of $\mathrm{Ag}^{+}$in solution. The sensitivity of Ag-ENPs to oxygen is well known (Liu and Hurt, 2010) and the chemisorbed $\mathrm{Ag}^{+}$, either formed in air (McMahon et al., 2005a; Lin and Frankel, 2013), during exposure to water (Li and Lenhart, 2012), or when in contact with detergents, can be easily released once the textile is laundered. However, the dissolution process is complex, with the extent and rate of dissolution being dependent on a multitude of factors ranging from solution chemistry to redox environment to particle specific characteristics and method of ENP incorporation into the fabric (Misra et al., 2012; Mitrano et al., 2014a). Quadros et al. assessed the potential for Ag ENP exposure to children from a blanket, plush toy, and a variety of other non-textile items (Quadros et al., 2013). Methods of simulated release varied to mimic product use. The authors concluded that the exposure risk to children would be low, similar to Kulthong et al. (2010). For example, an area of the fabric that was exposed to sweat or urine released a small amount of silver until the particles became coated in $\mathrm{AgCl}$, thereafter inhibiting further ionic release. Additionally, von Goetz et al. demonstrated that dissolved $\mathrm{Ag}$ was released from fabrics exposed to sweat, with Ag-chloro-complexes being the major dissolved species due to the high chloride content in sweat (von Götz et al., 2013). Incorporation of Ag ENP into textiles affords easy contact with air on the fabrics' surface, and transformations seen in Section 3.1 are likely.

Characterization of Ag ENP transformation was also performed through the laundry wash cycle. Mitrano et al. described the extent of $\mathrm{Ag}$ in various size fractions released from laboratory prepared textiles treated with either nano or conventional textile Ag additives (Mitrano et al., 2014b). The largest released fraction from both sets of textiles was the $>0.45 \mu \mathrm{m}$ fraction, where Ag may have been attached to fabric strings and/or detergent floc that was trapped on the filter. The highest total and proportional Ag concentrations were released from the conventional opposed to nano-textiles, where even $\mathrm{Ag}$ particulate in the nano range was higher from the conventional materials. The fraction of $\mathrm{Ag}$ which remains on the textiles after washing is also of interest and was found to vary from $\mathrm{Ag}(0), \mathrm{AgCl}, \mathrm{Ag}_{2} \mathrm{~S}, \mathrm{Ag}$-phosphate and ionic $\mathrm{Ag}$ (Lombi et al., 2014). Furthermore, washing with different detergents showed a marked difference between the Ag species that were detected. Follow-up studies are currently underway to better understand how multiple washings of the same textiles will affect the release of $\mathrm{Ag}$ (over time) and/or if changes in Ag speciation during the first wash changes the subsequent Ag release in further washings. Finally, transformations might occur to the particles that are still embedded in the textile when drying, through friction, hot air and/or humidity.

\subsection{Sunscreens, cosmetics, personal care products and cleaning agents}

Transformation of ENPs used in sunscreens and cosmetics (Table 2) is of particular interest because there is a high exposure potential; both for human exposure since the products are intended to be used regularly and directly on the body, and for environmental exposure after use ( $\mathrm{Mu}$ and Sprando, 2010; Henkler et al., 2012). $\mathrm{TiO}_{2}$, $\mathrm{ZnO}$, or Ag ENPs are dispersed in products and will be readily released during product use: sunscreens and cosmetics are washed off during bathing or swimming and almost all of the original product is released either into wastewater or directly into rivers or other water bodies (Davis et al., 2010; Gondikas et al., 2014). Estimates of ENP release from these items 


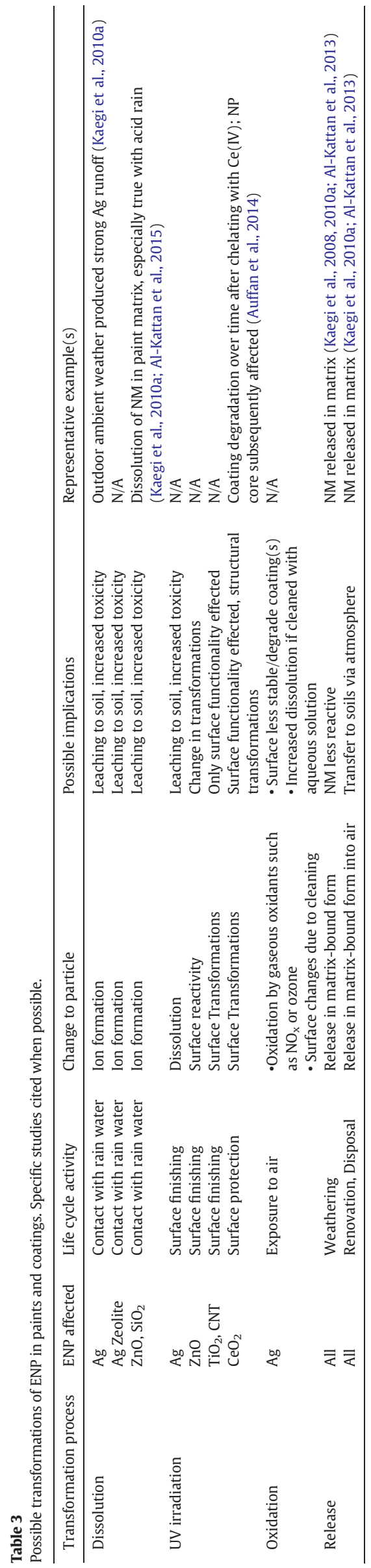

during use range from 75\% to 95\% (Mueller and Nowack, 2008; Keller et al., 2013).

$\mathrm{TiO}_{2}$ particles themselves are photocatalytic (Barnes et al., 2013; Tsuang et al., 2008), but this effect is minimized through coating the particles with magnesium, silica, alumina, zirconium and/or in combination with various organic coatings to ensure their safety in lotions and to prevent the generation of reactive oxygen species (Pan et al., 2009; Carlotti et al., 2009). Over time, these inert coatings may break down if they are not able to withstand UV illumination or dispersion in water during the lifecycle, therefore exposing the $\mathrm{TiO}_{2}$ core (Auffan et al., 2010). While surface transformation of the particle coating in part or in whole is likely, the particle core itself will probably remain intact. An exception to this is given by Holbrook et al., 2013 where the researchers found the predominant fraction of Ti in pool water to be dissolved (David Holbrook et al., 2013). Variable efficiency of the coatings to protect particles during direct (Nakagawa et al., 1997) and indirect UV exposure, in addition to modifications during different exposure scenarios, has been observed. For example, Auffan et al. noted that during the aging of $\mathrm{TiO}_{2}$ ENP with two successive protective layers (one organic, one inorganic) used in cosmetics, 90\% of the total Si of the organic layer was desorbed while the remaining fraction was surface oxidized (Auffan et al., 2010). The inorganic layer (consisting of $\left.\mathrm{Al}(\mathrm{OH})_{3}\right)$ was affected to a lower extent and continued to protect against photocatalytic superoxide formation. Degradation byproducts of the same material were tested by Labille et al. under simulated natural sunlight and water chemistry, where the authors found that depending on solution $\mathrm{pH}$, ionic strength, and natural organic matter (NOM) concentration, variable amounts of aggregation and settling of $\mathrm{TiO}_{2}$ ENPs were observed. Aging commercial sunscreens to access transformations over their life cycle, Botta et al. found that a significant fraction of $\mathrm{TiO}_{2}$ ENP residues were released from four of the commercially available sunscreens tested. The creams were submitted to artificial aging simulating drastic environmental conditions (UV/visible irradiation, water and stirring) (Botta et al., 2011) which resulted in agglomeration and sedimentation of the ENPs. In swimming pool water, protective coatings may be stripped from $\mathrm{TiO}_{2}$ particles (Virkutyte et al., 2012) and in some cases even result in dissolved species in the water (David Holbrook et al., 2013).

$\mathrm{ZnO}$ particles will experience the same light and aqueous environment as $\mathrm{TiO}_{2}$ particles, but transformation products will be significantly different (Lewicka et al., 2013). Exposure to water will induce dissolution if/when the surface coating is desorbed (Reed et al., 2012). In certain water systems, such as pool water, oxidants present may increase the rate of coating degradation. After ion formation, Zn carbonate may precipitate, especially in fresh and sea waters (Gelabert et al., 2014).

Both $\mathrm{TiO}_{2}$ and $\mathrm{ZnO}$ ENPs may also be altered via soaps and/or detergents during shampooing the hair/body or laundering of clothing. Addition of surfactants may result in a more stable ENP suspension as a whole by creating micelles. Phosphate containing detergents (where sold) may form Zn phosphates. EDTA, a chelating agent, is known to dissolve and subsequently stabilize metals in solution. Notably, some of these transformations may happen in tandem (e.g. UV plus oxidation in pool water) while others have sequential transformation steps (e.g. $\mathrm{ZnO}$ dissolution in water then re-precipitation as zinc carbonate or zinc phosphate).

\subsection{Paints and coatings}

Outdoor weathering conditions, such as UV irradiation, rain, and pollution, can both chemically and physically alter ENPs (Table 3). $\mathrm{TiO}_{2}$ has the capability to absorb UV irradiation and which can extend excellent weatherproofing properties to paints, potentially prolonging product life (Kumar et al., 2009). While initial UV illumination and ROS generation appears to positively influence paint qualities, the oxidation which occurs at the surface layer during weathering eventually erodes the particle coating leaving an exposed particle surface (Marolt et al., 2011; 
Christensen et al., 1999). This gives rise to either "chalking" of the paint or release of ENP (agglomerates) as the paint ages. In one instance, Kaegi et al. found that $\mathrm{TiO}_{2}$ particles were detected in aged paint runoff and $85-90 \%$ of the total Ti was in the $20-300 \mathrm{~nm}$ size range (Kaegi et al., 2008, 2010a). Electron microscopy revealed that the released particles occurred both as agglomerates and as individual particles, but of specific importance was that they were still embedded in the organic binder. However, it has to be noted that in this study a conventional paint containing only pigment $\mathrm{TiO}_{2}$ was investigated and not a nano-paint. However, Al-Kattan et al. found similar matrix-bound particles in leaching studies with paints containing nano- $\mathrm{TiO}_{2}$ and nano- $\mathrm{SiO}_{2}$ (Al-Kattan et al., 2013, 2014, 2015). Kaegi et al. found a similar result when investigating Ag ENPs in aged paint, with some evidence from EDX analysis to suggest the formation/release of $\mathrm{Ag}_{2} \mathrm{~S}$. Depending on the nature of the $\mathrm{TiO}_{2}$ ENPs (synthesis process, annealing), the " $\mathrm{TiO}_{2} \mathrm{ENP}$ film” can show super hydrophilic properties (Thongsuwan et al., 2011) that are susceptible to increase the surface degradation rate. These studies suggest that the behavior of ENP actually used in products is much more complex than the study of ENPs in water (Ottofuelling et al., 2011).

Conversely, the incorporation of ZnO ENPs significantly reduces the extent of photo degradation of the host matrix due to its superior UV light screening effects, increasing the durability of paints. Because the particles dissolve, there is no issue with chalking or ENP release (Klingshirn, 2007, 2010). Thus, unlike $\mathrm{TiO}_{2}$ particles, the ZnO ENPs will degrade and dissolve. This would be especially evident in areas suffering from acid rain, which with a $\mathrm{pH}$ ranging from 5 to 6 has the capability to totally leach the $\mathrm{Zn}$ from the paint matrix over time.

Ag ENPs dissolve readily and will wash out of the paint into rainwater. Paints containing nano-Ag that were exposed to ambient outdoor weather for one year showed strong leaching of ENPs (mostly $<15 \mathrm{~nm}$, attached to the organic binders of the paint) during initial runoff events (Kaegi et al., 2010b). The released particles showed the possible presence of $\mathrm{Ag}_{2} \mathrm{~S}$ formed from trace amounts of sulfur species present in the atmosphere and/or $\mathrm{Ag}_{2} \mathrm{O}$. In cities, effects of $\mathrm{NO}_{\mathrm{x}}$ from car exhausts and the effects of ozone both have the potential to oxidize the surface of the particles over time. Additionally, the influence of seasons with hot/cold cycles can degrade the paint matrix allowing increased release of NP into the environment.

Ag ENP coatings are being developed for a range of applications (Wong et al., 2006; Cohen et al., 2007; Clement et al., 2012), generally focusing around the medical field (Knetsch and Koole, 2011) and include coatings on medical instruments (Eby et al., 2009) and surfaces (Knetsch and Koole, 2011), in catheters (Stevens et al., 2009; Roe et al., 2008) and in wound dressings (Silver et al., 2006; Pollini et al., 2009). Exposure to oxidants in cleaning agents likely will dissolve the Ag particles (He et al., 2012; Ho et al., 2010). Depending on oxidant strength/exposure time, this may just oxidize the particle surface or capping agent of the particle. More degradation (oxidation, transformation, etc.) may occur after multiple exposures to oxidants, i.e. multiple cleaning events. This subsequent use would change the transformation behavior but there has been little study on how these dilute, multiple exposures to oxidants affect the persistence of coatings.

Other niche coatings are being developed with nano-additives, such as $\mathrm{CeO}_{2}$ for wood protection. The long-term behavior of $\mathrm{CeO}_{2}$ based nanocomposite used as a UV filter in wood stains was investigated under artificial daylight by Auffan et al. (2014) In this case, the particles' citrate coating was completely gone by 42 days and after 112 days only a small amount of degradation product could be detected on the surface. Furthermore, the coating degradation lead to further structural changes of the primary $\mathrm{CeO}_{2}$ core, a tandem process that should be considered when the engineered surface coating is removed by many processes.

\subsection{Plastics and polymers}

ENPs used in commercial plastics and polymers may be transformed during either product use or after disposal (Table 4). Many ENP- 


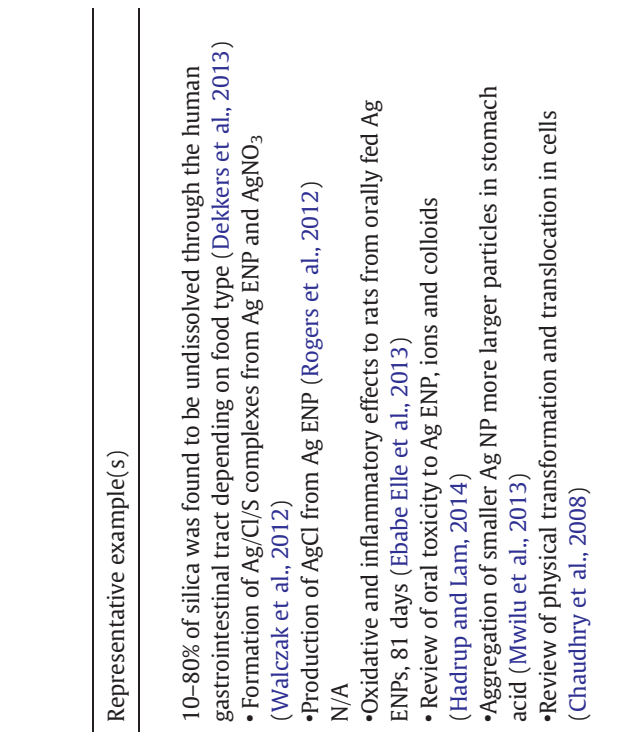

enhanced (composite) plastics and polymers are intended for outdoor use and thus will be exposed to UV rays (Froggett et al., 2014). Destructive oxidation of the polymer matrix may be reduced through surface treatments of the imbedded particles. For $\mathrm{TiO}_{2}$ ENP composites, part of the process leading to the polymer breakdown is induced by the photoactivity of $\mathrm{TiO}_{2}$ ENPs via localized sites on the particle surface. Coating the particles would occupy these "defect sites" and inhibit the reduction of $\mathrm{TiO}_{2}$ by UV light and, consequently, prevent some destruction of the polymer binder (Allen et al., 2004; Petersen et al., 2014). Exposure of nano-doped polymers to UV light was studied by Nguyen et al. (2012), where amine-cured epoxies doped with either $\mathrm{SiO}_{2} \mathrm{NP}$ or MWCNT exposed to realistic environmental conditions $\left(50{ }^{\circ} \mathrm{C}, 75 \%\right.$ relative humidity) showed variable mass losses created by photooxidative chain scission. The same behavior was observed with other polymer composites (see Najafi and Shin for instance (Najafi and Shin, 2005)). In such configurations, induced aging proceeds via oxidation on the surface layers of the composite material, which eventually erodes. Continuing on the work of Nguyen et al., Gorham and colleagues observed macroscopic changes to the polymer matrix through degradation, such as increased roughness and the appearance of cracks (Gorham et al., 2012). It has also been shown that after UV irradiation, a polymer can degrade while a MWCNT network remains intact (Wohlleben et al., 2013). ENPs tended to gather at the surface and thus release of the embedded particles was made possible, provided that extra mechanical energy was applied and/or there was poor dispersion of the particles in the matrix (Golanski et al., 2012).

Changes to the $\mathrm{TiO}_{2}$ coating may occur during the acid wash step of recycling, but the core particle would be resistant to change. Both $\mathrm{ZnO}$ and Ag ENPs would entirely dissolve during this cleaning process. If CNTs are embedded in a polymer and the polymer degrades, the coating/functionality on the CNT surface would also likely degrade. Physical transformations may include breaking, such as when CNTs are released from polymers or when a polymer is abraded (Petersen et al., 2014), oxidation of whole tubes, and surface oxidation of the tubes (either the coating or the surface of the tubes themselves). Natural water and/or sunlight (photo-oxidation) can affect the colloidal stability of CNTs (Hou et al., 2014).

\subsection{ENP in the food sector: additives, supplements, containers and packaging}

Nanotechnology applications in the food sector aim to altering the texture of food components, developing new tastes and sensations, controlling the release of flavors, encapsulating food components or additives, and/or increasing the bioavailability of nutrients (Chaudhry et al., 2008; Buzby, 2010). Food grade $\mathrm{TiO}_{2}$ is available by the ton for use in the food and beverage markets and it represents the bulk of commercially used whiteners in these industries (Weir et al., 2012). $\mathrm{Ag}$ ENP is incorporated into food products as a nutraceutical (health supplement) or to prohibit bacterial and fungal growth (Sozer and Kokini, 2012; Chaudhry et al., 2008). Ingestion of ENP-enhanced food or drink is the main pathway for both human exposure and ENP transformation (Table 5). When exposed to synthetic human stomach fluid, particles were shown to have changed zeta potential, aggregation and morphology in addition to producing silver chloride (Rogers et al., 2012; Mwilu et al., 2013). Ag ENP and $\mathrm{AgNO}_{3}$ in saliva, gastric and intestinal digestion also formed silver chloride and/or associated with Ag NP clusters. In the presence of proteins, particles comprised of silver, sulfur and chlorine were found (Walczak et al., 2012). The dissolution of silica nanoparticles from food under the conditions in the human gastrointestinal tract was investigated by Dekkers et al, where $80 \%$ of all silica from coffee creamer introduced into the system was found to be undissolved nanosilica, while for other food items (soup, pancakes) this figure was less (Dekkers et al., 2013).

Incorporation of ENPs into food packaging materials may have several advantages ranging from extension of food life to improved food safety to alerting consumers of food contamination or spoiling. 
Additional benefits include antimicrobial activity, creating a barrier against movement of gasses, volatile components (such as flavors) or moisture, increased polymer mechanical strength, decreased package weight and eco-friendly biodegradable qualities (Chaudhry et al., 2008; Sozer and Kokini, 2009, 2012; Sekhon, 2010; Azeredo, 2009; Sorrentino et al., 2007; Duncan, 2011). Some food storage products featuring nanosilver for their antimicrobial properties are commercially available (Chaudhry et al., 2008). When Ag ENPs are incorporated into polymers, they can be engineered for controlled releases allowing the antimicrobial agents to remain potent for a longer period of time. Several factors influence the longevity of Ag ENP or ionic release from polymers including the degree of polymer crystallinity, filler type (i.e. silver particles, zeolites, etc.), hydrophobicity of the matrix and particle size (Duncan, 2011). Hypothetically, when Ag ENP enhanced food containers and packaging are recycled or disposed of, $\mathrm{Ag}^{+}$ions may leach from the product either during acid washing (pre-recycling step) or when in contact with water (disposed in landfill).

As is the case with many plastic additives, Ag ENPs are not covalently bound to the plastic matrix and are intended to be released during use. The main consumer concern around nano-enhanced food storage is the migration onto/into the food or drink for consumption. The ENPs would experience a similar fate as consumption, outlined above. Migration of Ag ENPs from plastic bags into food simulants was studied by Huang et al. and Hauri et al, where Ag-impregnated plastic food containers were shown to release a maximum Ag concentration of $0.9 \mathrm{mg} / \mathrm{L}$ in $5 \%$ acetic acid after seven days (Huang et al., 2011; Hauri and Niece, 2011). However, in both studies Ag form was not determined. Research presented by von Goetz et al. differentiated between ionic and particulate $\mathrm{Ag}$ release from plastic food containers using different food simulants (von Goetz et al., 2013). Most of the Ag release was in ionic form, but approximately $12 \%$ was found as Ag NPs.

\subsection{The energy sector, fuels and catalysts}

Table 6 summarizes possible transformations in this field. $\mathrm{CeO}_{2} \mathrm{ENPs}$ are used as a diesel additive directly into fuel to catalytically promote soot oxidation and degradation. The fuel is exposed to high temperatures during use and any coatings on the ENP would be completely oxidized prior to release into the environment. The particle itself may stay intact, but surface $\mathrm{Ce}^{3+}$ could be oxidized to $\mathrm{Ce}^{4+}$, though no data currently exists on this hypothetical transformation during or after the combustion process (Nowack et al., 2012). Because most $\mathrm{CeO}_{2}$ ENPs are likely to be captured by diesel filters or the catalytic converter (Ulrich and Wichser, 2003), its pathway to the landfill and/or to recycling is considered to be very important (Park et al., 2008). Little is known about the precise quantities or pathways of how materials flow through recycling plants for any ENP. The fate and reactivity of nano- $\mathrm{CeO}_{2}$ once released into the atmosphere have yet to be fully investigated.

Carbon nanomaterials, like CNTs, fullerenes or soot, may result in the incomplete combustion of hydrocarbons. Their fate and transformation in the environment are still in debate. CNTs have been found to display adsorption properties towards $\mathrm{O}_{2}$ (Ulbricht et al., 2003) and $\mathrm{N}_{2}$ (Xu and $\mathrm{Li}, 2005$ ) but these highly crystalline structures seem to be quite stable towards oxidation by $\mathrm{O}_{2}$ or $\mathrm{O}_{3}$ (Majestic et al., 2010).

The catalytic properties of ENPs are also utilized in both fuel cells and solar energy applications. They are subjected to high temperatures and/ or high irradiance during use and the major concern in terms of aging is the alteration/reduction of the performances of these assemblies. It was found, for instance, that Au NPs deposited on Indium Tin Oxide electrodes (Kang et al., 2010) and Pt-Cu alloy NP electrocatalyst precursors (Koh and Strasser, 2010) decrease their electrocatalytic activities, even at ambient temperature. In the case of solar energy, thermal absorbers made of MWCNT/NiO composites, exposed for $200 \mathrm{~h}$ at $250{ }^{\circ} \mathrm{C}$, simulating a 25 year aging pattern under normal use conditions, induced a slight decrease in reflectance, correlated with decreases of $\mathrm{C} / \mathrm{Ni}$ and of particle size (Roro et al., 2012). Soot oxidation can also be promoted via catalytic converters. The thermal and chemical aging processes of the catalysts ( $\mathrm{Pt} / \mathrm{Al}_{2} \mathrm{O}_{3}, \mathrm{Pd} / \mathrm{Al}_{2} \mathrm{O}_{3}$, etc.) are well documented. Physical modifications of the catalysts induced by thermal aging (at $700{ }^{\circ} \mathrm{C}$ ) include decreased surface area and increased heterogeneity of the spatial distribution within the alloy (Matam et al., 2012, 2013). $\mathrm{TiO}_{2}$ is also widely used in solar cells (dye-sensitized solar cells, perovskite solar cells). As all the above examples are essentially closed systems that will go through a controlled disposal process (i.e. e-waste processing or disposal centers), there is little opportunity for ENPs to leach into the environment.

\subsection{Consumer electronics and semiconductors}

A large variety of ENPs are encountered in this domain of application. $\mathrm{ZnO}, \mathrm{ZnS}, \mathrm{Ag}, \mathrm{Al}$ oxides, $\mathrm{TiO}_{2}, \mathrm{Ag}, \mathrm{SiO}_{2}, \mathrm{Co}, \mathrm{CdS}$ and $\mathrm{CdSe}$ quantum dots, CNTs: virtually all ENPs are possible candidates to improve materials in this sector. For this review, we consider the transformations of $\mathrm{TiO}_{2}$ and $\mathrm{Ag}$ (Table 6). Considering $\mathrm{TiO}_{2}$ ENPs, if products are treated as e-waste after disposal then the products will be acid washed, and metals fractionated and collected. Only the surface or capping agent of the $\mathrm{TiO}_{2}$ particles would be affected, as acid washes are unlikely to dissolve the entire particle. If, however, consumer electronics are not specially recycled and are disposed of into a standard landfill, the landfill would be considered the final sink. Ag ENPs possess a strong surface plasmon-polariton resonance that makes them an interesting candidate for nanophotonics applications. However, this property was altered after the surface tarnished during aging in ambient air of nano-Ag arrays, observed as a decrease and red shift of the resonance peak

Table 6

Possible transformations of ENPs in consumer electronics, semiconductors, magnets and air filters. No studies could be cited here.

\begin{tabular}{|c|c|c|c|c|c|}
\hline $\begin{array}{l}\text { Transformation } \\
\text { process }\end{array}$ & ENP affected & Life cycle activity & Change to particle & Possible implications & $\begin{array}{l}\text { Representative } \\
\text { example(s) }\end{array}$ \\
\hline \multicolumn{6}{|c|}{ Possible transformations of ENPs in consumer electronics, semiconductors and magnets } \\
\hline \multirow[t]{2}{*}{ Acid wash } & $\mathrm{Ag}, \mathrm{ZnO}$ & Treatment of e-waste & Dissolution & Ion formation & $\mathrm{N} / \mathrm{A}$ \\
\hline & $\mathrm{TiO}_{2}$ & Treatment of e-waste & Surface transformations & Dissolve surface coating, bare particles behave differently & $\mathrm{N} / \mathrm{A}$ \\
\hline \multirow[t]{2}{*}{ Incineration } & CNT & Waste incineration & Destruction & Decreased risk from CNT & $\mathrm{N} / \mathrm{A}$ \\
\hline & ENP coating & All & Removal of organic coating & Change in stability & $\mathrm{N} / \mathrm{A}$ \\
\hline \multicolumn{6}{|c|}{ Possible transformations of ENPs in air filters } \\
\hline UV irradiation & All & Air filtration & Surface transformations & Oxidation of capping agent or direct oxidation of surface & $\mathrm{N} / \mathrm{A}$ \\
\hline \multirow[t]{3}{*}{ Incineration } & $\mathrm{TiO}_{2}$ & After disposal & Surface transformations & Organic particle coating/functionality burned but core intact & $\mathrm{N} / \mathrm{A}$ \\
\hline & CNT & After disposal & Combustion & $\begin{array}{l}\text { Dependent on CNT structure and incineration temperature. } \\
\text { No trace of ENP }\end{array}$ & $\mathrm{N} / \mathrm{A}$ \\
\hline & CNT & Product use & Incomplete Combustion & $\begin{array}{l}\text { Dependent on CNT structure and incineration temperature. } \\
\text { Preservation of CNT or change in surface properties }\end{array}$ & $\mathrm{N} / \mathrm{A}$ \\
\hline Combustion & $\mathrm{CeO}_{2}$ & Use of fuel & Surface Transformations & $\begin{array}{l}\text { Coating completely oxidized. Particle may stay intact but } \\
\text { change from } \mathrm{Ce} 3+\text { to } \mathrm{Ce} 4+\text {. }\end{array}$ & Hypothetical only \\
\hline
\end{tabular}


Table 7

Main chemical transformation reactions during use and disposal of nano-products.

\begin{tabular}{|c|c|c|c|c|c|c|}
\hline $\begin{array}{l}\text { Transformation } \\
\text { process }\end{array}$ & $\mathrm{ENP}(\mathrm{s})$ affected & $\begin{array}{l}\text { Main product } \\
\text { category }\end{array}$ & Governing factors & Example(s) of ENP change & Result of transformation & $\begin{array}{l}\text { Transformation: more similar or } \\
\text { more diverse NPs? }\end{array}$ \\
\hline $\begin{array}{l}\text { Oxidation and } \\
\text { reduction }\end{array}$ & $\mathrm{Ag}, \mathrm{Fe}, \mathrm{CeO}_{2}$ & All & $\begin{array}{l}\text { - Element (oxidation, } \\
\text { reduction or both } \\
\text { • Environmental factors (e.g. } \\
\text { redox potential) }\end{array}$ & $\begin{array}{l}\text { - Altered ratio of oxidized element in sample } \\
\text { - Prerequisite to ENP dissolution }\end{array}$ & $\begin{array}{l}\text { - Change to surface chemistry } \\
\text { - Potential for further } \\
\text { transformations (e.g. dissolution) }\end{array}$ & Often loss of nano-property \\
\hline Photochemistry & $\begin{array}{l}\mathrm{TiO}_{2}, \mathrm{ZnO}, \mathrm{SiO}_{2} \\
\mathrm{Ag}, \mathrm{CNT}\end{array}$ & $\begin{array}{l}\text { Cosmetics, textiles, } \\
\text { coatings/surfaces, } \\
\text { paints }\end{array}$ & $\begin{array}{l}\text { - Light intensity } \\
\text { - Ability of light to penetrate } \\
\text { outer coating/layers }\end{array}$ & $\begin{array}{l}\text { - Change to ENP coating } \\
\text { - Oxidation state } \\
\text { - Generation of reactive oxygen species (ROS) } \\
\text { - Particle persistence }\end{array}$ & $\begin{array}{l}\text { Change to surface chemistry, change } \\
\text { of crystallinity }\end{array}$ & $\begin{array}{l}\text { - A multitude of chemical and physical changes } \\
\text { to core or surface } \\
\text { • More diverse particles likely }\end{array}$ \\
\hline Dissolution & $\mathrm{Ag}, \mathrm{ZnO}$ & Textiles, cosmetics & $\begin{array}{l}\text { - Particle size } \\
\text { - Capping agent } \\
\text { - Composition } \\
\text { - Solution chemistry }\end{array}$ & $\begin{array}{l}\text { - ENP surface properties } \\
\text { - Toxicity } \\
\text { - Particle persistence }\end{array}$ & $\begin{array}{l}\text { Loss of nano-identity, formation of } \\
\text { secondary particles }\end{array}$ & Loss of nano-property, particles disappear \\
\hline Phase & & transformation & $\mathrm{Ag}, \mathrm{ZnO}, \mathrm{SiO}_{2}, \mathrm{CuO}$ & All & $\begin{array}{l}\text { - Particle size } \\
\text { - Capping agent } \\
\text { - Composition } \\
\text { - Solution chemistry }\end{array}$ & $\begin{array}{l}\text { - Sulfidation } \\
\text { •Phosphatization }\end{array}$ \\
\hline $\begin{array}{l}\text { Change to } \\
\text { particle } \\
\text { surface } \\
\text { chemistry, } \\
\text { change to } \\
\text { primary } \\
\text { particle } \\
\text { functionality }\end{array}$ & $\begin{array}{l}\text { More similar, } \\
\text { e.g. when } \\
\text { Ag-ENPs of } \\
\text { various size } \\
\text { and surface } \\
\text { coating become } \\
\text { AgS }\end{array}$ & & & & & \\
\hline $\begin{array}{l}\text { Absorption to } \\
\text { ENP surface }\end{array}$ & All materials & All & Solution chemistry & $\begin{array}{l}\text {-Agglomeration } \\
\text { - Organic ligands may affect dissolution, charge, and } \\
\text { stability }\end{array}$ & $\begin{array}{l}\text { Changes to particle surface } \\
\text { chemistry }\end{array}$ & $\begin{array}{l}\text { Depending on the case, this could make the } \\
\text { particle population more similar or more } \\
\text { diverse. }\end{array}$ \\
\hline $\begin{array}{l}\text { Desorption } \\
\text { from ENP } \\
\text { surface }\end{array}$ & All materials & All & $\begin{array}{l}\text { - Solution chemistry } \\
\text { - Particle composition }\end{array}$ & $\begin{array}{l}\text { Strongly affects the coatings of product-weathered } \\
\text { MNM's, especially if capping agent loosely bound to } \\
\text { MNM surface }\end{array}$ & $\begin{array}{l}\text { Changes to particle surface } \\
\text { chemistry }\end{array}$ & $\begin{array}{l}\text { If the same particle type becomes "bare" after } \\
\text { the coating(s) desorb, particle transformations } \\
\text { are more similar }\end{array}$ \\
\hline $\begin{array}{l}\text { Exposure to } \\
\text { extreme heat } \\
\text { (Incineration) }\end{array}$ & $\begin{array}{l}\text { CNT, ZnO, Ag } \\
\text { Surface: All }\end{array}$ & $\begin{array}{l}\text { All, at the end of life } \\
\text { cycle }\end{array}$ & $\begin{array}{l}\text { Disposal/waste stream } \\
\text { differences that vary by } \\
\text { country or region }\end{array}$ & $\begin{array}{l}\text { - Complete combustion of material } \\
\text { - Combustion only of surface coatings } \\
\text { - Melting } \\
\text { - Chlorination }\end{array}$ & $\begin{array}{l}\text { Loss of nano-properties (CNT, } \mathrm{ZnO} \text {, } \\
\mathrm{Ag} \text { ) or change to surface properties } \\
\left(\mathrm{TiO}_{2}, \mathrm{SiO}_{2}\right)\end{array}$ & $\begin{array}{l}\text { Loss of nano-property } \\
\text { The destruction of surface coatings will make } \\
\text { them more similar }\end{array}$ \\
\hline Re-Precipitation & $\mathrm{Ag}, \mathrm{ZnO}$ & $\begin{array}{l}\text { All, after } \mathrm{M}^{+} \text {release } \\
\text { from product }\end{array}$ & $\begin{array}{l}\text { Solution chemistry } \\
\text { Light }\end{array}$ & $\begin{array}{l}\text { - Sunlight driven photo-reduction of Ag metal } \\
\text { - Formation of Zn-carbonate after ZnO dissolution }\end{array}$ & New particle formation & $\begin{array}{l}\text { Formation of new NP: making less similar } \\
\text { particles }\end{array}$ \\
\hline
\end{tabular}


(McMahon et al., 2005b). This is attributed to the chemisorption of sulfur (via $\mathrm{H}_{2} \mathrm{~S}$ present in the air) and the conversion of $\mathrm{Ag}$ to $\mathrm{Ag}_{2} \mathrm{~S}$ on the nano-array surface. It is noteworthy that this reaction proceeds at a greater rate than at bulk Ag surfaces (a few nm/day) but preserves the spherical shape of the particles.

\subsection{Air filters}

Nanocatalysts can play a crucial role in air filtration applications related to odor removal and chemical/biological remediation. Photocatalytic process using thin film nano- $\mathrm{TiO}_{2}$ as an advanced oxidation process has emerged as a promising alternative to degrade VOCs directly (Kim and Hong, 2002; Obee and Brown, 1995; Yu et al., 2007) (Table 6). This could potentially extend the life of the filters, prevent secondary re-aerosolization of organic contaminants or biological organisms during maintenance and facilitate regeneration of the filters with UV illumination thereby decreasing the need for frequent replacement (Woan et al., 2009). ENP can also be incorporated into everyday items such as curtains, blinds, or glass where naturally available UV sources are used to purify air, as well as to destroy pathogenic microorganisms (Chengyu et al., 2003; Guo et al., 2009; Kaneko and Okura, 2002).
$\mathrm{TiO}_{2}$ ENPs incorporated into the filter matrix will be disposed of as e-waste, in landfills, or incinerated. Landfills are complex system but are considered final sinks here. If incinerated, only surface transformations would occur on the nano- $\mathrm{TiO}_{2}$ and the unchanged core would either accumulate in the bottom ash or fly ash. Some CNTs may be burned and some may not, depending on CNT structure and incineration temperature. In some incinerators, there may be cooler pockets inside where all CNTs may not combust and thus also remain in the ash. The non-combusted tubes may be transformed through oxidation of the surface or physical breakage of the tubes themselves (Petersen et al., 2011). At this time, only mathematical modeling is available to determine the flows of ENPs during waste handling and so specific transformations need to be confirmed experimentally (Mueller et al., 2013).

\section{Implications of transformation reactions}

5.1. Grouping particle transformation processes through the life cycle of nano-products

This review provides a baseline for which ENMs are used in different product groups and subsequently the various transformation reactions possible during exposure to different media through the life cycle. The major determinant for the type of transformation reaction is the use of

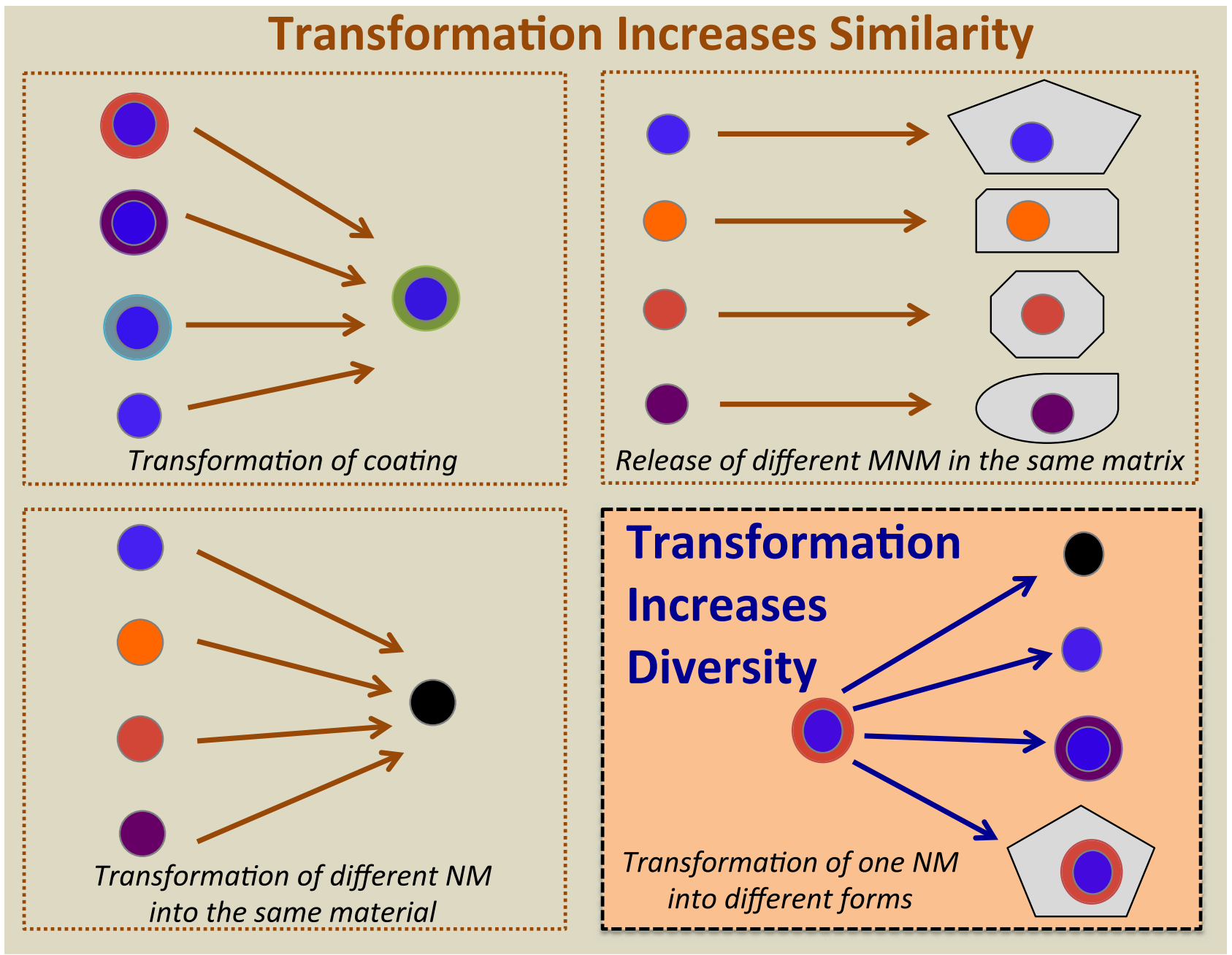

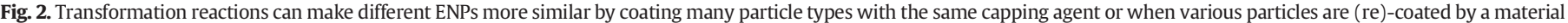

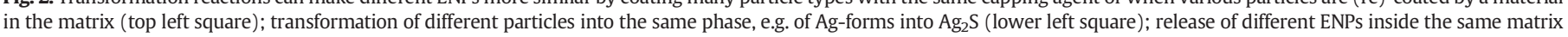

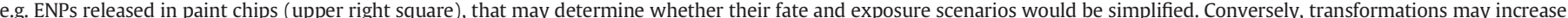

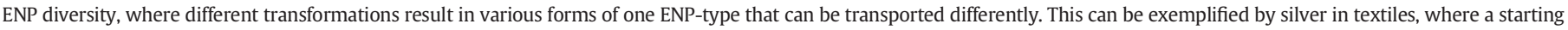
material can be transformed into $\mathrm{Ag} / \mathrm{S}, \mathrm{AgCl} \mathrm{Ag}^{+}$, etc. during the wash cycle (lower right square). 
the nano-products that results in different materials exposed to different environments and conditions. However, several commonalities exist and we can draw some general conclusions. Nanomaterials exhibit the same chemical reactions as the bulk form of the materials undergoes, so traditional knowledge on metal and metal oxide chemistry can be broadly applied in many instances, with subtle adjustments concerning nano-specific reactions where appropriate. For example, the literature on corrosion is full of information on the transformation reactions of compounds such as Ag that are driven by thermodynamics, resulting in dissolution and phase transformation reactions. When extending this information to ENMs, some of these reactions result in complete loss of the nano-properties, either because the particle has been dissolved or transformed into particles larger than $100 \mathrm{~nm}$. In these cases, an assessment of the NP is no longer necessary but only of the metal it was composed of. On the other hand, some transformation reactions may only change the NP partially, for example the surface coating. Table 7 summarizes the main transformation reactions we have identified, the particle(s) they affect and the products categories for which it is important. For each transformation process, the main affected ENP and product categories are given. The main chemical or physical factors that govern the reaction are listed together with examples of the change of the ENP and the result of the transformation reaction. The final column indicates if the reaction leads to a more similar or more diverse set of particles.

From the above discussion, it will be of interest to determine if the released and subsequently transformed ENPs result in a more similar or more diverse set of ENPs (Fig. 2). Though extensive data are not available in this area, some scenarios may be: 1) Transformation reactions of the particle coatings, effectively making ENPs to behave more similar, 2) chemical reactions of the particles making different ENPs more similar (e.g. transformation of different $\mathrm{Ag}$ ENPs all to $\mathrm{Ag}_{2} \mathrm{~S}$ ), 3) particles released but bound in the matrix (e.g. released $\mathrm{TiO}_{2}$ and $\mathrm{Ag}$ ENP from paints), or 4) different aging/transformation reactions acting on one ENP-type resulting in different transformation products. For different stress situations (mechanical, thermal, chemical) important processes should be identified for either product groups (i.e. textiles, polymers, etc.) and/or ENP groups (i.e. chemical makeup) and standardized release risk assessment protocols implemented for defined conditions. Finally, reporting the results of experiments should be standardized to include a key set of metrics upon which to more easily compare one study to the next.

\subsection{Implication for future risk assessment protocols}

Nanostructured materials have come into play in the consumer market after a relatively short development period. ENPs have been studied extensively for their desirable characteristics in relation to the development of products with distinct performance advantages but decidedly less is known about how the materials will transform under mechanical, biological and environmental stresses. This situation is further complicated because materials that are chemically similar could be implemented into a variety of different products, each having a different life cycle. Depending on product specific transformations, different toxicological profiles and environmental fates could be possible for the same particle under different use conditions. Most products are assessed for toxicity and potential environmental harm on a cradle-to-gate basis, rather than on a cradle-to-grave basis. This leaves the onus for safe disposal on the consumer, public waste facilities, and regulatory bodies (Meyer et al., 2009).

ENPs may be released from products in a matrix-bound form or as agglomerates, with potentially lesser fractions as single, dispersed particles (Froggett et al., 2014). This physical alteration could be beneficial for environmental health, as smaller sized agglomerates appear to be less toxic, have decreased reactivity compared to free NPs, and settle in sediments thereby slowing the movement of particles through the environment (Lowry et al., 2012). ENPs that are still embedded in the nano-product will have environmental behavior closely linked with the properties of the matrix. However, this is product specific and will be highly dependent on the manufactured, tunable interactions between the particle surface coating and the matrix. With more research and development in this area, this interaction may be optimized over time, either to purposefully leach particles or retain them in the matrix. Surface coatings of the particles can play an important role in the stability of particles in both the short and long term. Alternatively some ENPs, such as $\mathrm{Ag}$ and $\mathrm{ZnO}$, will dissolve and release ions. Agglomeration of particles, such as when used in sprays and sunscreens, effects particles fate in the longer term because there is little evidence they would revert to their initial suspension (Auffan et al., 2010; Labille et al., 2010). Finally, various temporal scales for assessment of fate and behavior would be appropriate depending on the product and/or the environment that the particles are released in.

It is clear that the released fraction of ENPs from nano-products no longer represents the primary particles initially dispersed in the matrix, but rather, a variety of different fragments, agglomerates, and transformed products that have significantly different physical and chemical properties than the original, as manufactured ENPs. The implementation of additional real-world studies is called for to produce realistic information on the fate of ENPs after product releases for environmental, toxicological, and modeling efforts. The true challenge lies in determining if the alteration of commercial ENPs/nano-products will release particles that have high(er) reactivity, or rather, if weathering will lead to various kinds of passivation (compared to the pristine or asmanufactured ENPs) through surface morphology, adsorption, surface redox evolution, or other mechanisms. This may necessitate guidance regarding which material testing protocols should be employed for different ENPs that differ to a certain degree. As risk assessment begins to adopt the incorporation of product modified ENP in EHS studies, and not just the pristine material, scientists and the public will begin to have a more holistic picture of the true health and environmental impacts the growing field of nanotechnology may pose.

\subsection{Moving toward building a useable database}

Life cycle thinking in the context of nanotechnology is currently in its infancy. Potential advantages and improvements using ENPs are promoted constantly with less systematic understanding of what properties of ENP in products could be harmful or produce unintended side effects. Specifically, better understanding of how the particles could transform through the life cycle to produce "unexpected" health and environmental consequences is important. The key is to make information useful in a wider context, standardizing experimental results and determining which metric(s) are crucial for characterizing and predicting ENP transformations during release and exposure throughout the product life cycle.

A significant gap appears to be identifying each stage of the ENP life cycle and thus potential exposure and transformation hot-spots, which may include (but are not limited to): occupational exposure during fullscale and down-stream uses, consumer exposure during product use, and environmental release during product recycling or after disposal. Research and development activities in nanotechnology about in the literature, but generally there is a lack of detailed descriptions of the precise ENP under study, precautions taken to prevent environmental release, or the use patterns of the ENP in question.

In terms of predicting ENP fate, at this stage simple correlations between transformations and physical-chemical properties of pristine ENPs are still difficult because of the myriad of particle types, capping agents, and complexity of the systems being studied. Often, a change in one parameter will significantly change the extent of transformation and determining how multiple factors may co-vary is exceedingly difficult. While some studies give suggestions as to the persistence of ENPs under relevant environmental conditions, fewer delve into the topic of biopersistence and toxicity of matrix bound particles. Since 
these are likely release scenarios, these aged products need to be further investigated.

\section{Acknowledgments}

This work was funded by the European Commission within the Seventh Framework Program (FP7; NanoMILE project-Grant Agreement:NMP4-LA-2013-310451).

\section{References}

Ali, M., Winterer, M., 2009. ZnO nanocrystals: surprisingly 'alive'. Chem. Mater. 22 (1), 85-91. Alivisatos, A.P., 1996. Perspectives on the physical chemistry of semiconductor nanocrystals. J. Phys. Chem. 100 (31), 13226-13239.

Al-Kattan, A., Wichser, A., Vonbank, R., Brunner, S., Ulrich, A., Zuin, S., Nowack, B., 2013. Release of $\mathrm{TiO}_{2}$ from paints coating pigment $\mathrm{TiO}_{2}$ or nano- $\mathrm{TiO}_{2}$ by weathering. Environ. Sci. Process. Impacts 15 (12), 2186-2193.

Al-Kattan, A. Wichser, A., Vonbank, R., Brunner, S., Ulrich, A., Zuin, S, Arroyo, Y., Golanski, L., Nowack, B., 2015. Characterization of materials released into water from paint containing nano-SiO ${ }_{2}$. Chemosphere 119, 1314-1321.

Al-Kattan, A., Wichser, A., Zuin, S., Arroyo, Y., Golanski, L., Ulrich, A., Nowack, B., 2014. Behavior of $\mathrm{TiO}_{2}$ released from nano- $\mathrm{TiO}_{2}$ containing paint and comparison to pristine nano-TiO 2 . Environ. Sci. Technol. 48, 6710-6718.

Allen, N.S., Edge, M., Corrales, T., Childs, A., Liauw, C.M., Catalina, F., Peinado, C., Minihan, A., Aldcroft, D., 1998. Ageing and stabilisation of filled polymers: an overview. Polym. Degrad. Stab. 61 (2), 183-199.

Allen, N.S., Edge, M., Ortega, A., Sandoval, G., Liauw, C.M., Verran, J., Stratton, J., McIntyre, R.B., 2004. Degradation and stabilisation of polymers and coatings: nano versus pigmentary titania particles. Polym. Degrad. Stab. 85 (3), 927-946.

Association of National Biosolids and Regulartion, 2007. Quality, End Use \& Disposal Survey - Final Report.

Auffan, M., Pedeutour, M., Rose, J., Masion, A., Ziarelli, F., Borschneck, D. Chaneac, C., Botta, C., Chaurand, P., Labille, J., 2010. Structural degradation at the surface of a $\mathrm{TiO}_{2}$-based nanomaterial used in cosmetics. Environ. Sci. Technol. 44 (7), 2689-2694.

Auffan, M., Masion, A., Labille, J., Diot, M.-A., Liu, W., Olivi, L., Proux, O., Ziarelli, F. Chaurand, P., Geantet, C., 2014. Long-term aging of a $\mathrm{CeO}_{2}$ based nanocomposite used for wood protection. Environ. Pollut. 188, 1-7.

Azeredo, H., 2009. Nanocomposites for food packaging applications. Food Res. Int. 42 (9), $1240-1253$.

Barnes, R.J., Molina, R., Xu, J., Dobson, P.J., Thompson, I.P., 2013. Comparison of $\mathrm{TiO}_{2}$ and $\mathrm{ZnO}$ nanoparticles for photocatalytic degradation of methylene blue and the correlated inactivation of gram-positive and gram-negative bacteria. J. Nanoparticle Res. 15 (2), $1-11$.

Benn, T., Westerhoff, P., 2008. Nanoparticle silver released into water from commercially available sock fabrics. Environ. Sci. Technol. 42 (11), 4133-4139.

Benn, T., Cavanagh, B., Hristovski, K., Posner, J.D., Westerhoff, P., 2010. The release of nanosilver from consumer products used in the home. J. Environ. Qual. 39, $1875-1882$

Botta, C., Labille, J., Auffan, M., Borschneck, D., Miche, H., Cabié, M., Masion, A., Rose, J. Bottero, J.-Y., 2011. $\mathrm{TiO}_{2}$-based nanoparticles released in water from commercialized sunscreens in a life-cycle perspective: structures and quantities. Environ. Pollut. 159 (6), 1543-1550.

Buzby, J.C., 2010. Nanotechnology for food applications: more questions than answers. J. Consum. Aff. 44 (3), 528-545.

Carlotti, M.E., Ugazio, E., Sapino, S., Fenoglio, I., Greco, G., Fubini, B., 2009. Role of particle coating in controlling skin damage photoinduced by titania nanoparticles. Free Radic Res. 43 (3), 312-322.

Chaudhry, Q., Scotter, M., Blackburn, J., Ross, B., Boxall, A., Castle, L., Aitken, R., Watkins, R. 2008. Applications and implications of nanotechnologies for the food sector. Food Addit. Contam. 25 (3), 241-258.

Cheng, Y., Yin, L., Lin, S., Wiesner, M., Bernhardt, E., Liu, J., 2011. Toxicity reduction of polymerstabilized silver nanoparticles by sunlight. J. Phys. Chem. C 115 (11), 4425-4432.

Chengyu, W., Huamei, S., Ying, T., Tongsuo, Y., Guowu, Z., 2003. Properties and morphology of CdS compounded $\mathrm{TiO}_{2}$ visible-light photocatalytic nanofilms coated on glass surface. Sep. Purif. Technol. 32 (1), 357-362.

Christensen, P., Dilks, A., Egerton, T., Temperley, J., 1999. Infrared spectroscopic evaluation of the photodegradation of paint: part I: the UV degradation of acrylic films pigmented with titanium dioxide. J. Mater. Sci. 34 (23), 5689-5700.

Clement, K., Iseli, A., Karote, D., Cremer, J., Rajagopalan, S., 2012. Nanostructured materials: industrial applications. Handbook of Industrial Chemistry and Biotechnology. Springer, pp. 265-306.

Cohen, M.S., Stern, J.M., Vanni, A.J., Kelley, R.S., Baumgart, E., Field, D., Libertino, J.A., Summerhayes, I.C., 2007. In vitro analysis of a nanocrystalline silver-coated surgical mesh. Surg. Infect. 8 (3), 397-404.

David Holbrook, R., Motabar, D., Quiñones, O., Stanford, B., Vanderford, B., Moss, D., 2013. Titanium distribution in swimming pool water is dominated by dissolved species. Environ. Pollut. 181, 68-74.

Davis, J., Wang, A., Shtakin, J., 2010. Nanomaterial Case Studies: Nanoscale Titanium Dioxide in Water Treatment and in Topical Sunscreen. US EPA, Research Triangle Park, NC.

Dekkers, S., Bouwmeester, H., Bos, P.M., Peters, R.J., Rietveld, A.G., Oomen, A.G., 2013 Knowledge gaps in risk assessment of nanosilica in food: evaluation of the dissolution and toxicity of different forms of silica. Nanotoxicology 7 (4), 367-377.
Duncan, T.V., 2011. Applications of nanotechnology in food packaging and food safety: barrier materials, antimicrobials and sensors. J. Colloid Interface Sci. 363 (1), 1-24.

Ebabe Elle, R., Gaillet, S., Vidé, J., Romain, C., Lauret, C., Rugani, N., Cristol, J., Rouanet, J., 2013. Dietary exposure to silver nanoparticles in Sprague-Dawley rats: effects on oxidative stress and inflammation. Food Chem. Toxicol. 60, 297-301.

Eby, D.M., Luckarift, H.R., Johnson, G.R., 2009. Hybrid antimicrobial enzyme and silver nanoparticle coatings for medical instruments. ACS Appl. Mater. Interfaces 1 (7), $1553-1560$.

Flores-Cervantes, D.X., Maes, H.M., Schäffer, A., Hollender, J., Kohler, H.-P.E., 2014. Slow biotransformation of carbon nanotubes by horseradish peroxidase. Environ. Sci. Technol. 48 (9), 4826-4834.

Froggett, S., Clancy, S., Boverhof, D., Canady, R., 2014. A review and perspective of existing research on the release of nanomaterials from solid nanocomposites. Part. Fibre Toxicol. 11 (17)

Gelabert, A., Sivry, Y., Ferrari, R., Akrout, A., Cordier, L., Nowak, S., Menguy, N., Benedetti, M.F., 2014. Uncoated and coated $\mathrm{ZnO}$ nanoparticles life cycle in synthetic seawater. Environ. Toxicol. Chem. 22 (2), 341-349.

Geranio, L., Heuberger, M., Nowack, B., 2009. The behavior of silver nanotextiles during washing. Environ. Sci. Technol. 43 (21), 8113-8118.

Glover, R.D., Miller, J.M., Hutchison, J.E., 2011. Generation of metal nanoparticles from silver and copper objects: nanoparticle dynamics on surfaces and potential sources of nanoparticles in the environment. ACS Nano 5 (11), 8950-8957.

Golanski, L., Guiot, A., Pras, M., Malarde, M., Tardif, F., 2012. Release-ability of nano fillers from different nanomaterials (toward the acceptability of nanoproduct). J. Nanoparticle Res. 14 (7).

Gondikas, A.P., Von Der Kammer, F., Reed, R.B., Wagner, S., Ranville, J.F., Hofmann, T., 2014. Release of $\mathrm{TiO}_{2}$ nanoparticles from sunscreens into surface waters: a oneyear survey at the old Danube recreational lake. Environ. Sci. Technol. 48 (10), 5415-5422.

Gorham, J.M., Nguyen, T., Bernard, C., Stanley, D., Holbrook, R.D., 2012. Photo-induced surface transformations of silica nanocomposites. Surf. Interface Anal. 44 (13), $1572-1581$

Gottschalk, F., Scholz, R., Nowack, B., 2010. Probabilistic material flow modeling for assessing the environmental exposure to compounds: methodology and an application to engineered nano- $\mathrm{TiO}_{2}$ particles. Environ. Model. Softw. 25 (3), 320-332.

Guo, S., Wu, Z., Zhao, W., 2009. $\mathrm{TiO}_{2}$-based building materials: above and beyond traditional applications. Chin. Sci. Bull. 54 (7), 1137-1142.

Hadrup, N., Lam, H.R., 2014. Oral toxicity of silver ions, silver nanoparticles and colloidal silver-a review. Regul. Toxicol. Pharmacol. 68 (1), 1-7.

Handy, R., Owen, R., Valsami-Jones, E., 2008. The ecotoxicology of nanoparticles and nanomaterials: current status, knowledge gaps, challenges, and future needs. Ecotoxicology 17 (5), 315-325.

Hauri, J.F., Niece, B.K., 2011. Leaching of silver from silver-impregnated food storage containers. J. Chem. Educ. 88 (10), 1407-1409.

He, D., Garg, S., Waite, T.D., 2012. $\mathrm{H}_{2} \mathrm{O}_{2}$-mediated oxidation of zero-valent silver and resultant interactions among silver nanoparticles, silver ions, and reactive oxygen species. Langmuir 28, 10266-10275.

Henkler, F., Tralau, T., Tentschert, J., Kneuer, C., Haase, A., Platzek, T., Luch, A., Götz, M.E., 2012. Risk assessment of nanomaterials in cosmetics: a European Union perspective. Arch. Toxicol. 86 (11), 1641-1646.

Ho, C.M., Yau, S.K.W., Lok, C.N., So, M.H., Che, C.M., 2010. Oxidative dissolution of silver nanoparticles by biologically relevant oxidants: a kinetic and mechanistic study. Chem. Asian J. 5 (2), 285-293.

Hou, W.-C., BeigzadehMilani, S., Jafvert, C.T., Zepp, R.G., 2014. Photoreactivity of unfunctionalized single-wall carbon nanotubes involving hydroxyl radical: chiral dependency and surface coating effect. Environ. Sci. Technol. 48 (7), 3875-3882.

Huang, H.H., Ni, X.P., Loy, G.L., Chew, C.H., Tan, K.L., Loh, F.C., Deng, J.F., Xu, G.Q., 1996. Photochemical formation of silver nanoparticles in poly(N-vinylpyrrolidone). Langmuir 12 (4), 909-912.

Huang, Y., Chen, S., Bing, X., Gao, C., Wang, T., Yuan, B., 2011. Nanosilver migrated into food-simulating solutions from commercially available food fresh containers. Packag. Technol. Sci. 24 (5), 291-297.

Impellitteri, C., Scheckel, T., Kirk, G., 2009. The speciation of silver nanoparticles in antimicrobial fabric before and after exposure to hypochlorite/detergent solution. J. Environ. Qual. 38, 1528-1530.

Impellitteri, C.A., Harmon, S., Silva, R.G., Miller, B.W., Scheckel, K.G., Luxton, T.P., Schupp, D., Panguluri, S., 2013. Transformation of silver nanoparticles in fresh, aged, and incinerated biosolids. Water Res. 47 (12), 3878-3886.

Kaegi, R., Ulrich, A., Sinnet, B., Vonbank, R., Wichser, A., Zuleeg, S., Simmler, H., Brunner, S., Vonmont, H., Burkhardt, M., Boller, M., 2008. Synthetic $\mathrm{TiO}_{2}$ nanoparticle emission from exterior facades into the aquatic environment. Environ. Pollut 156, 233-239.

Kaegi, R., Sinnet, B., Zuleeg, S., Hagendorfer, H., Mueller, E., Vonbank, R., Boller, M., Burkhardt, M., 2010a. Release of silver nanoparticles from outdoor facades. Environ. Pollut. 158, 2900-2905.

Kaegi, R., Sinnet, B., Zuleeg, S., Hagendorfer, H., Mueller, E., Vonbank, R., Boller, M., Burkhardt, M., 2010b. Release of silver nanoparticles from outdoor facades. Environ. Pollut. 158 (9), 2900-2905.

Kaegi, R., Voegelin, A., Sinnet, B., Zuleeg, S., Hagendorfer, H., Burkhardt, M., Siegrist, H., 2011. Behavior of metallic silver nanoparticles in a pilot wastewater treatment plant. Environ. Sci. Technol. 45, 3902-3908.

Kaegi, R., Voegelin, A., Ort, C., Sinnet, B., Thalmann, B., Krismer, J., Hagendorfer, H., Elumelu, M., Mueller, E., 2013. Fate and transformation of silver nanoparticles in urban wastewater systems. Water Res. 47 (12), 3866-3877.

Kalinina, A., 2014. Material flow modeling, environmental concentrations and environmental risk assessment for nanosilica. Masters Thesis. ETH Zurich.

Kaneko, M., Okura, I., 2002. Photocatalysis: Science and Technology. Springer. 
Kang, H.J., Patra, S., Das, J., Aziz, A., Jo, J., Yang, H., 2010. Effect of aging on the electrocatalytic activity of gold nanoparticles. Electrochem. Commun. 12 (9), 1245-1248.

Katari, J.B., Colvin, V.L., Alivisatos, A.P., 1994. X-ray photoelectron spectroscopy of CdSe nanocrystals with applications to studies of the nanocrystal surface. J. Phys. Chem. 98 (15), 4109-4117.

Keller, A.A., McFerran, S., Lazareva, A., Suh, S., 2013. Global life cycle releases of engineered nanomaterials. J. Nanoparticle Res. 15 (6), 1-17.

Kenning, G.G., Heidt, C., Barnes, A., Martin, J., Grove, B., Madden, M., 2011. Thermally activated magnetization and resistance decay during near ambient temperature aging of Co nanoflakes in a confining semi-metallic environment. J. Appl. Phys. 110 (11), 114312.

$\mathrm{Kim}, \mathrm{H} ., 2$ 2003. Corrosion process of silver in environments containing $0.1 \mathrm{ppm} \mathrm{H}_{2} \mathrm{~S}$ and $1.2 \mathrm{ppm} \mathrm{NO}$. Mater. Corros. 54 (4), 243-250.

Kim, S.B., Hong, S.C., 2002. Kinetic study for photocatalytic degradation of volatile organic compounds in air using thin film $\mathrm{TiO}_{2}$ photocatalyst. Appl. Catal. B Environ. 35 (4), 305-315.

Kiser, M., Westerhoff, P., Benn, T., Wang, Y., Perez-Rivera, J., Hristovski, K., 2009. Titanium nanomaterial removal and release from wastewater treatment plants. Environ. Sci. Technol. 43 (17), 6757-6763.

Klaine, S.J., Koelmans, A.A., Horne, N., Carley, S., Handy, R., Kapustka, L., Nowack, B., Von der Kammer, F., 2012. Paradigms to assess the environmental impact of manufactured nanomaterials. Environ. Toxicol. Chem. 31 (1), 3-14.

Klingshirn, C., 2007. ZnO: material, physics and applications. ChemPhysChem 8 (6), 782-803.

Klingshirn, C.F., 2010. Zinc Oxide: From Fundamental Properties Towards Novel Applications vol. 120. Springer.

Knetsch, M.L., Koole, L.H., 2011. New strategies in the development of antimicrobial coatings: the example of increasing usage of silver and silver nanoparticles. Polymers 3 (1), 340-366.

Koh, S., Strasser, P., 2010. Dealloyed Pt nanoparticle fuel cell electrocatalysts: stability and aging study of catalyst powders, thin films, and inks. J. Electrochem. Soc. 157 (4), B585-B591.

Köhler, A.R., Som, C., Helland, A., Gottschalk, F., 2008. Studying the potential release of carbon nanotubes throughout the application life cycle. J. Clean. Prod. 16 (8), 927-937.

Kuhlbusch, T., Fissan, H., Asbach, C., 2009. Nanotechnologies and environmental risks. Nanomaterials: Risks and Benefits. Springer, pp. 233-243.

Kulthong, K., Srisung, S., Boonpavanitchakul, K., Kangwansupamonkon, W., Maniratanachote, R., 2010. Determination of silver nanoparticle release from antibacterial fabrics into artificial sweat. Part. Fibre Toxicol. 7 (8), 1-9.

Kumar, A.P., Depan, D., Singh Tomer, N., Singh, R.P., 2009. Nanoscale particles for polymer degradation and stabilization-trends and future perspectives. Prog. Polym. Sci. 34 (6), 479-515.

Labille, J., Feng, J., Botta, C., Borschneck, D., Sammut, M., Cabie, M., Auffan, M., Rose, J., Bottero, J.-Y., 2010. Aging of $\mathrm{TiO}_{2}$ nanocomposites used in sunscreen. Dispersion and fate of the degradation products in aqueous environment. Environ. Pollut. 158 (12), 3482-3489.

Levard, C., Hotze, E.M., Lowry, G.V., Brown Jr., G.E., 2012. Environmental transformations of silver nanoparticles: impact on stability and toxicity. Environ. Sci. Technol. 46 (13), 6900-6914.

Levard, C., Mitra, S., Yang, T., Jew, A.D., Badireddy, A.R., Lowry, G.V., Brown, G.E., 2013. Effect of chloride on the dissolution rate of silver nanoparticles and toxicity to E. coli. Environ. Sci. Technol. 47 (11), 5738-5745

Lewicka, Z.A., Yu, W.W., Oliva, B.L, Contreras, E.Q., Colvin, V.L, 2013. Photochemical behavior of nanoscale $\mathrm{TiO}_{2}$ and $\mathrm{ZnO}$ sunscreen ingredients. J. Photochem. Photobiol. A Chem. 263, 24-33.

Li, X., Lenhart, J.., 2012. Aggregation and dissolution of silver nanoparticles in natural surface water. Environ. Sci. Technol. 46 (10), 5378-5386.

Lin, H., Frankel, G., 2013. Accelerated atmospheric corrosion testing of Ag. Corrosion 69 (11), $1060-1072$.

Liu, J., Hurt, R., 2010. Ion release kinetics and particle persistence in aqueous nano-silver colloids. Environ. Sci. Technol. 44 (6), 2169-2175.

Lombi, E., Donner, E., Scheckel, K.G., Sekine, R., Lorenz, C., Goetz, N.V., Nowack, B., 2014. Silver speciation and release in commercial antimicrobial textiles as influenced by washing. Chemosphere 111, 352-358.

Lorenz, C., Windler, L., von Goetz, N., Lehmann, R., Schuppler, M., Hungerbühler, K. Heuberger, M., Nowack, B., 2012. Characterization of silver release from commercially available functional (nano) textiles. Chemosphere 89 (7), 817-824.

Lowry, G.V., Gregory, K.B., Apte, S.C., Lead, J.R., 2012. Transformations of nanomaterials in the environment. Environ. Sci. Technol. 46 (13), 6893-6899.

Majestic, B.J., Erdakos, G.B., Lewandowski, M., Oliver, K.D., Willis, R.D., Kleindienst, T.E., Bhave, P.V., 2010. A review of selected engineered nanoparticles in the atmosphere sources, transformations, and techniques for sampling and analysis. Int. J. Occup. Environ. Health 16 (4), 488-507.

Marolt, T., Škapin, A.S., Bernard, J., Živec, P., Gaberšček, M., 2011. Photocatalytic activity of anatase-containing facade coatings. Surf. Coat. Technol. 206 (6), 1355-1361.

Matam, S.K., Otal, E.H., Aguirre, M.H., Winkler, A., Ulrich, A., Rentsch, D., Weidenkaff, A., Ferri, D., 2012. Thermal and chemical aging of model three-way catalyst $\mathrm{Pd} / \mathrm{Al}_{2} \mathrm{O}_{3}$ and its impact on the conversion of CNG vehicle exhaust. Catal. Today 184 (1), 237-244.

Matam, S.K., Kondratenko, E.V., Aguirre, M.H., Hug, P., Rentsch, D., Winkler, A. Weidenkaff, A., Ferri, D., 2013. The impact of aging environment on the evolution of $\mathrm{Al}_{2} \mathrm{O}_{3}$ supported Pt nanoparticles and their NO oxidation activity. Appl. Catal. B Environ. 129, 214-224.

McMahon, M., Lopez, R., Meyer III, H., Feldman, L., Haglund Jr., R., 2005a. Rapid tarnishing of silver nanoparticles in ambient laboratory air. Appl. Phys. B 80 (7), 915-921.

McMahon, M., Lopez, R., Meyer, H.M., Feldman, L.C., Haglund, R.F., 2005b. Rapid tarnishing of silver nanoparticles in ambient laboratory air. Appl. Phys. B Lasers Opt. 80 (7), 915-921.
Meyer, D.E., Curran, M.A., Gonzalez, M.A., 2009. An examination of existing data for the industrial manufacture and use of nanocomponents and their role in the life cycle impact of nanoproducts. Environ. Sci. Technol. 43 (5), 1256-1263.

Michel, K., Scheel, J., Karsten, S., Stelter, N., Wind, T., 2013. Risk assessment of amorphous silicon dioxide nanoparticles in a glass cleaner formulation. Nanotoxicology 7 (5), 974-988.

Misra, S.K., Dybowska, A., Berhanu, D., Luoma, S.N., Valsami-Jones, E., 2012. The complexity of nanoparticle dissolution and its importance in nanotoxicological studies. Sci. Total Environ. 438, 225-232.

Mitrano, D.M., Ranville, J., Bednar, A., Kazor, K., Hering, A.S., Higgins, C., 2014a. Tracking dissolution of silver nanoparticles at environmentally relevant concentrations in laboratory, natural and processed waters using single particle ICP-MS (spICP-MS). Environ. Sci. Nano 1 (3), 248-259.

Mitrano, D.M., Rimmele, E., Wichser, A., Erni, R., Height, M., Nowack, B., 2014b. Presence of nanoparticles in wash water from conventional silver and nano-silver textiles. ACS Nano 8 (7), 7208-7219.

Mu, L., Sprando, R.L., 2010. Application of nanotechnology in cosmetics. Pharm. Res. 27 (8), 1746-1749

Mudunkotuwa, I.A., Pettibone, J.M., Grassian, V.H., 2012. Environmental implications of nanoparticle aging in the processing and fate of copper-based nanomaterials Environ. Sci. Technol. 46 (13), 7001-7010.

Mueller, N., Nowack, B., 2008. Exposure modeling of engineered nanoparticles in the environment. Environ. Sci. Technol. 42 (12), 4447-4453.

Mueller, N.C., Buha, J., Wang, J., Ulrich, A., Nowack, B., 2013. Modeling the flows of engineered nanomaterials during waste handling. Environ. Sci. Process. Impacts 15 (1), 251-259

Mwilu, S.K., El Badawy, A.M., Bradham, K., Nelson, C., Thomas, D., Scheckel, K.G., Tolaymat, T., Ma, L., Rogers, K.R., 2013. Changes in silver nanoparticles exposed to human synthetic stomach fluid: effects of particle size and surface chemistry. Sci. Total Environ. 447, 90-98.

Najafi, E., Shin, K., 2005. Radiation resistant polymer-carbon nanotube nanocomposite thin films. Colloids Surf. A Physicochem. Eng. Asp. 257-58, 333-337.

Nakagawa, Y., Wakuri, S., Sakamoto, K., Tanaka, N., 1997. The photogenotoxicity of titanium dioxide particles. Mutat. Res. Genet. Toxicol. Environ. Mutagen. 394 (1), 125-132.

Nguyen, T., Pellegrin, B., Bernard, C., Rabb, S., Stuztman, P., Gorham, J.M., Gu, X., Yu, L.L. Chin, J.W., 2012. Characterization of surface accumulation and release of nanosilica during irradiation of polymer nanocomposites by ultraviolet light. J. Nanosci. Nanotechnol. 12 (8), 6202-6215.

Nowack, B., Bucheli, T., 2007. Occurrence, behavior and effects of nanoparticles in the environment. Environ. Pollut. 150 (1), 5-22.

Nowack, B., Ranville, J.F., Diamond, S., Gallego-Urrea, J.A., Metcalfe, C., Rose, J., Horne, N., Koelmans, A.A., Klaine, S.J., 2012. Potential scenarios for nanomaterial release and subsequent alteration in the environment. Environ. Toxicol. Chem. 31 (1), 50-59.

Nowack, B., David, R.M., Fissan, H., Morris, H., Shatkin, J.A., Stintz, M., Zepp, R., Brouwer, D. 2013. Potential release scenarios for carbon nanotubes used in composites. Environ. Int. 59, 1-11.

Obee, T.N., Brown, R.T., 1995. $\mathrm{TiO}_{2}$ photocatalysis for indoor air applications: effects of humidity and trace contaminant levels on the oxidation rates of formaldehyde, toluene, and 1, 3-butadiene. Environ. Sci. Technol. 29 (5), 1223-1231.

O'Brien, N., Cummins, E., 2010. Ranking initial environmental and human health risk resulting from environmentally relevant nanomaterials. J. Environ. Sci. Health A 45 (8), 992-1007.

Ottofuelling, S., Von Der Kammer, F., Hofmann, T., 2011. Commercial titanium dioxide nanoparticles in both natural and synthetic water: comprehensive multidimensional testing and prediction of aggregation behavior. Environ. Sci. Technol. 45 (23), $10045-10052$

Pan, Z., Lee, W., Slutsky, L., Clark, R.A., Pernodet, N., Rafailovich, M.H., 2009. Adverse effects of titanium dioxide nanoparticles on human dermal fibroblasts and how to protect cells. Small 5 (4), 511-520.

Park, B., Donaldson, K., Duffin, R., Tran, L., Kelly, F., Mudway, I., Morin, J.-P., Guest, R. Jenkinson, P., Samaras, Z. 2008. Hazard and risk assessment of a nanoparticulate cerium oxide-based diesel fuel additive-a case study. Inhal. Toxicol. 20 (6), 547-566.

Petersen, E.J., Zhang, L., Mattison, N.T., O'Carroll, D.M., Whelton, A.J., Uddin, N., Nguyen, T. Huang, Q., Henry, T.B., Holbrook, R.D., 2011. Potential release pathways, environmental fate, and ecological risks of carbon nanotubes. Environ. Sci. Technol. 45 (23), 9837-9856

Petersen, E.J., Lam, T., Gorham, J.M., Scott, K.C., Long, C.J., Stanley, D., Sharma, R., Alexander Liddle, J., Pellegrin, B., Nguyen, T., 2014. Methods to assess the impact of UV irradiation on the surface chemistry and structure of multiwall carbon nanotube epoxy nanocomposites. Carbon 69, 194-205.

Pollini, M., Russo, M., Licciulli, A., Sannino, A., Maffezzoli, A., 2009. Characterization of antibacterial silver coated yarns. J. Mater. Sci. Mater. Med. 20 (11), 2361-2366.

Quadros, M., Pierson IV, R., Tulve, N., Willis, R., Rogers, K., Thomas, T., Marr, L.C., 2013. Release of silver from nanotechnology-based consumer products for children. Environ. Sci. Technol. 47 (15), 8894-8901.

Reed, R.B., Ladner, D.A., Higgins, C.P., Westerhoff, P., Ranville, J.F., 2012. Solubility of nanozinc oxide in environmentally and biologically important matrices. Environ. Toxicol. Chem. 31 (1), 93-99.

Reed, R.B., Goodwin, D.G., Marsh, K.L., Capracotta, S.S., Higgins, C.P., Fairbrother, D.H., Ranville, J.F., 2013. Detection of single walled carbon nanotubes by monitoring embedded metals. Environ. Sci. Process. Impacts 15 (1), 204-213.

Reidy, B., Haase, A., Luch, A., Dawson, K.A., Lynch, I., 2013. Mechanisms of silver nanoparticle release, transformation and toxicity: a critical review of current knowledge and recommendations for future studies and applications. Materials 6 (6), 2295-2350.

Rice, D., Peterson, P., Rigby, E.B., Phipps, P., Cappell, R., Tremoureux, R., 1981. Atmospheric corrosion of copper and silver. J. Electrochem. Soc. 128 (2), 275-284. 
Roe, D., Karandikar, B., Bonn-Savage, N., Gibbins, B., Roullet, J.-B., 2008. Antimicrobia surface functionalization of plastic catheters by silver nanoparticles. J. Antimicrob. Chemother. 61 (4), 869-876.

Roes, L., Patel, M.K., Worrell, E., Ludwig, C., 2012. Preliminary evaluation of risks related to waste incineration of polymer nanocomposites. Sci. Total Environ. 417, 76-86.

Rogers, K.R., Bradham, K., Tolaymat, T., Thomas, D.J., Hartmann, T., Ma, L., Williams, A., 2012. Alterations in physical state of silver nanoparticles exposed to synthetic human stomach fluid. Sci. Total Environ. 420, 334-339.

Roro, K.T., Mwakikunga, B., Tile, N., Yalisi, B., Forbes, A., 2012. Effect of accelerated thermal ageing on the selective solar thermal harvesting properties of multiwall carbon nanotube/nickel oxide nanocomposite coatings. Int. J. Photoenergy. Article ID 678394

Savolainen, K., Alenius, H., Norppa, H., Pylkkänen, L., Tuomi, T., Kasper, G., 2010. Risk assessment of engineered nanomaterials and nanotechnologies-a review. Toxicology 269 (2), 92-104.

Sekhon, B.S., 2010. Food nanotechnology-an overview. Nanotechnol. Sci. Appl. 3 (10) $1-15$.

Silver, S., Phung, L.T., Silver, G., 2006. Silver as biocides in burn and wound dressings and bacterial resistance to silver compounds. J. Ind. Microbiol. Biotechnol. 33 (7), 627-634.

Som, C., Berges, M., Chaudhry, Q., Dusinska, M., Fernandes, T.F., Olsen, S.I., Nowack, B., 2010. The importance of life cycle concepts for the development of safe nanoproducts. Toxicology 269 (2), 160-169.

Sorrentino, A., Gorrasi, G., Vittoria, V., 2007. Potential perspectives of bio-nanocomposites for food packaging applications. Trends Food Sci. Technol. 18 (2), 84-95.

Sozer, N., Kokini, J.L., 2009. Nanotechnology and its applications in the food sector. Trends Biotechnol. 27 (2), 82-89.

Sozer, N., Kokini, J.L., 2012. The applications of nanotechnology. Chemical Analysis of Food-Techniques and Applications. Academic, Elsevier, pp. 145-176.

Stevens, K.N. Crespo-Biel, O, van den Bosch, E.E, Dias, A.A, Knetsch, M.L, Aldenhoff, Y.B. van der Veen, F.H., Maessen, J.G., Stobberingh, E.E., Koole, L.H., 2009. The relationship between the antimicrobial effect of catheter coatings containing silver nanoparticles and the coagulation of contacting blood. Biomaterials 30 (22), 3682-3690.

Sun, T.Y., Gottschalk, F., Hungerbühler, K., Nowack, B., 2014. Comprehensive probabilistic modelling of environmental emissions of engineered nanomaterials. Environ. Pollut. 185, 69-76.

Thongsuwan, W., Kumpika, T., Singjai, P., 2011. Effect of high roughness on a long aging time of superhydrophilic $\mathrm{TiO}_{2}$ nanoparticle thin films. Curr. Appl. Phys. 11 (5), $1237-1242$.

Thurber, A.P., Alanko, G., Beausoleil II, G.L., Dodge, K.N., Hanna, C., Punnoose, A., 2012. Unusual crystallite growth and modification of ferromagnetism due to aging in pure and doped ZnO nanoparticles. J. Appl. Phys. 111 (7), 07C319.

Tripathi, A.K., Singh, M.K., Mathpal, M.C., Mishra, S.K., Agarwal, A., 2013. Study of structural transformation in $\mathrm{TiO}_{2}$ nanoparticles and its optical properties. J. Alloys Compd. 549, 114-120.

Tsuang, Y.H., Sun, J.S., Huang, Y.C., Lu, C.H., Chang, W.H.S., Wang, C.C., 2008. Studies of photokilling of bacteria using titanium dioxide nanoparticles. Artif. Organs 32 (2), 167-174.

Ulbricht, H., Moos, G., Hertel, T., 2003. Interaction of molecular oxygen with single-wall carbon nanotube bundles and graphite. Surf. Sci. 532, 852-856.

Ulrich, A., Wichser, A., 2003. Analysis of additive metals in fuel and emission aerosols of diesel vehicles with and without particle traps. Anal. Bioanal. Chem. 377 (1), 71-81.
Virkutyte, J., Al-Abed, S.R., Dionysiou, D.D., 2012. Depletion of the protective aluminum hydroxide coating in $\mathrm{TiO}_{2}$-based sunscreens by swimming pool water ingredients. Chem. Eng. J. 191, 95-103.

Volpe, L., Peterson, P., 1989. The atmospheric sulfidation of silver in a tubular corrosion reactor. Corros. Sci. 29 (10), 1179-1196.

von Goetz, N., Fabricius, L., Glaus, R., Weitbrecht, V., Günther, D., Hungerbühler, K., 2013. Migration of silver from commercial plastic food containers and implications for consumer exposure assessment. Food Addit. Contam. A 30 (3), 612-620.

von Götz, N., Lorenz, C., Windler, L., Nowack, B., Heuberger, M.P., Hungerbuehler, K., 2013. Migration of $\mathrm{Ag}$-and $\mathrm{TiO}_{2}$-(nano) particles from textiles into artificial sweat under physical stress: experiments and exposure modeling. Environ. Sci. Technol. 47 (17), 9979-9987.

Walczak, A.P., Fokkink, R., Peters, R., Tromp, P., Herrera Rivera, Z.E., Rietjens, I.M., Hendriksen, P.J., Bouwmeester, H., 2012. Behaviour of silver nanoparticles and silver ions in an in vitro human gastrointestinal digestion model. Nanotoxicology 1-13.

Walser, T., Limbach, L.K., Brogioli, R., Erismann, E., Flamigni, L., Hattendorf, B., Juchli, M., Krumeich, F., Ludwig, C., Prikopsky, K., 2012. Persistence of engineered nanoparticles in a municipal solid-waste incineration plant. Nat. Nanotechnol. 7 (8), 520-524.

Watanabe, M., Shinozaki, S., Toyoda, E., Asakura, K., Ichino, T., Kuwaki, N., Higashi, Y., Tanaka, T., 2006. Corrosion products formed on silver after a one-month exposure to urban atmospheres. Corrosion 62 (3), 243-250.

Weir, A. Westerhoff, P., Fabricius, L., Hristovski, K, von Goetz, N., 2012. Titanium dioxide nanoparticles in food and personal care products. Environ. Sci. Technol. 46 (4), 2242-2250

Westerhoff, P., Song, G., Hristovski, K., Kiser, M.A., 2011. Occurrence and removal of titanium at full scale wastewater treatment plants: implications for $\mathrm{TiO}_{2}$ nanomaterials. J. Environ. Monit. 13 (5), 1195-1203.

Windler, L., Lorenz, C., von Goetz, N., Hungerbühler, K., Amberg, M., Heuberger, M., Nowack, B., 2012. Release of titanium dioxide from textiles during washing. Environ. Sci. Technol. 46 (15), 8181-8188.

Woan, K., Pyrgiotakis, G., Sigmund, W., 2009. Photocatalytic carbon-nanotube-TiO2 composites. Adv. Mater. 21 (21), 2233-2239.

Wohlleben, W., Meier, M.W., Vogel, S., Landsiedel, R., Cox, G., Hirth, S., Tomović, Ž., 2013. Elastic CNT-polyurethane nanocomposite: synthesis, performance and assessment of fragments released during use. Nanoscale 5 (1), 369-380.

Wong, Y., Yuen, C., Leung, M., Ku, S., Lam, H., 2006. Selected applications of nanotechnology in textiles. AUTEX Res. J. 6 (1), 1-8.

$\mathrm{Xu}$, Y.J., Li, J.Q., 2005. The interaction of N-2 with active sites of a single-wall carbon nanotube. Chem. Phys. Lett. 412 (4-6), 439-443.

Yan, Y., Yang, H., Li, J., Lu, X., Wang, C., 2012. Release behavior of nano-silver textiles in simulated perspiration fluids. Text. Res. J. 82 (14), 1422-1429.

Yin, F., Wang, Z.W., Palmer, R.E., 2012. Ageing of mass-selected $\mathrm{Cu} / \mathrm{Au}$ and $\mathrm{Au} / \mathrm{Cu}$ core/ shell clusters probed with atomic resolution. J. Exp. Nanosci. 7 (6), 703-710.

Yu, H., Zhang, K., Rossi, C., 2007. Experimental study of the photocatalytic degradation of formaldehyde in indoor air using a nano-particulate titanium dioxide photocatalyst. Indoor Built Environ. 16 (6), 529-537.

Yuan, Z., Chen, Y., Li, T., Yu, C.-P., 2013. Reaction of silver nanoparticles in the disinfection process. Chemosphere 93 (4), 619-625. 